Southern Methodist University

SMU Scholar

Faculty Journal Articles and Book Chapters

Faculty Scholarship

2016

\title{
'Protection and Empire': The Martens Clause, State Sovereignty, and Individual Rights
}

Jeffrey D. Kahn

Southern Methodist University, Dedman School of Law

Author ORCID Identifier:

(iD) https://orcid.org/0000-0002-8857-5647

\section{Recommended Citation}

Jeffrey Kahn, Protection and Empire: The Martens Clause, State Sovereignty, and Individual Rights, 56 Va. J. Int'I L. 1 (2016)

This document is brought to you for free and open access by the Faculty Scholarship at SMU Scholar. It has been accepted for inclusion in Faculty Journal Articles and Book Chapters by an authorized administrator of SMU Scholar. For more information, please visit http://digitalrepository.smu.edu. 


\title{
"Protection and Empire": The Martens Clause, State Sovereignty, and Individual Rights
}

\author{
JEFFREY KAHN ${ }^{*}$
}

The Martens Clause was a last-minute compromise that saved the 1899 Hague Convention with Respect to the Laws and Customs of War on Land. In its original formulation, the clause sbielded individuals under "the protection and empire" of international law, principles of bumanity, and the dictates of the public conscience. F. F. Martens, its author, was Russia's greatest international law scholar and an extraordinary diplomat. He saw no application for his work in the nineteenth-century internal affairs of states, notwithstanding the transnational terrorism that plagued (and ultimately destroyed) the Russian Empire. Martens's worldview is no longer our own. State sovereignty is no longer an absolute value in public international law, in part because of the well-known buman rights revolution of the twentieth century. As a result, the reach and importance of the Martens Clause has grown. This history helps refute the claim that international bumanitarian law is ill-suited for twenty-first century transnational terrorism. But the Clause is not, and never was, a panacea.

\footnotetext{
* Professor of Law, Southern Methodist University Dedman School of Law. B.A. 1994, Yale; M.Phil. 1996, Oxford; D.Phil. 1999, Oxford; J.D. 2002, Michigan. This Article is based on remarks made at the Major General John L. Fugh Symposium on Law and Military Operations, U.S. Army Judge Advocate General's Legal Center and School, May 14, 2014. A draft was completed while a visiting professor at the Washington \& Lee School of Law. I thank Washington \& Lee for such an excellent environment to read, think, and write, and the staff of the Virginia Journal of International Law for their five-star editorial work. I also thank Professor Bobby Chesney and Brigadier General Richard Gross, with whom I shared the Fugh Symposium panel, and Geoff Corn, Mark Drumbl, Chris Jenks, René Provost, and Ken Watkin for their helpful comments. I remain wholly responsible for the contents of this Article.
} 
INTRODUCTION

I. THE UNITED STATES AND TRANSNATIONAL TERRORISM ...........................

II. THE RUSSIAN EMPIRE AND TRANSNATIONAL TERRORISM ........................13

III. THE MARTENS CLAUSE ........................................................................ 18

IV. "ProteCTION \& EMPIRE": INDIVIDUAL RigHTS AND SOVEREIGNTY. 27

A. Individual Rigbts and Sovereignty in Martens's Day .....................................31

B. Individual Rights and Sovereignty in Our Day..............................................36

C. The Martens Clause and Armed Conflict.......................................................4

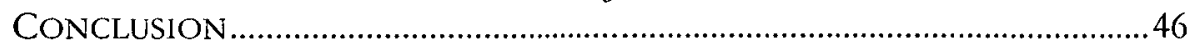

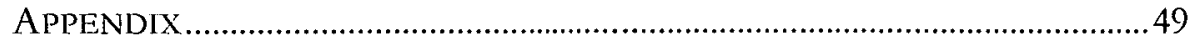

Terrorist Attacks in Moscow, January 1, 1998 to January 24, 2011 ...................49

INTRODUCTION

Until a more complete code of the laws of war is issued, the High Contracting Parties think it right to declare that in cases not included in the Regulations adopted by them, populations and belligerents remain under the protection and empire of the principles of international law, as they result from the usages established between civilized nations, from the laws of humanity, and the requirements of the public conscience.

- The Martens Clause (1899) ${ }^{1}$

In May 2014, a symposium at the U.S. Army's Judge Advocate General's Legal Center and School opened with a question: "Is the use of force against al-Qaeda and associated forces, globally, justified in the context of a continuing transnational armed conflict?" 2 If justified, the symposium organizers asked, what law governs this so-called transnational armed conflict? Virtually the same questions occupied experts at the Hague in a conference sponsored by the International Committee of the Red Cross (ICRC) in June 2003.3

More than a decade after the start of what then-President George W. Bush called the "war on terror," it may seem strange that these jus ad bellum and jus in bello questions remain unresolved. Their answers, however, turn

1. Preamble to Convention with Respect to the Laws and Customs of War on Land, July 29, 1899, reprinted in TeXTS OF THE PLACE CONFERLNCES AT THE HAGUE, 1899 AND 1907, at 48 (James Brown Scott ed., 1908).

2. Program, Major General John L. Fugh Symposium on Law and Military Operations, U.S. Army Judge Advocate General's Legal Center and School (May 14, 2014) (on file with author).

3. INTERNATIONAL COMMITTEE OF THE RED CROSS, INTERNATIONAL HUMANITARIAN LAW AND THE CHALLIENGES OF CONTEMPORARY ARMED CONFLICTS 31 (2003) [hereinafter ICRC 28TH CONFERENCE REPORT) ("The debate focused on whether the use of force against transnational non-state actors could qualify as armed conflict (international or non-international).'). 
out to be devilishly complicated. With whom is the United States fighting? What international legal status does this adversary (or these adversaries) possess? Under what body of law should its fighters be held accountable? What legal duties correspond to the law authorizing a state to fight an entity that, whatever else it may be, is not a sovereign nation-state?

Behind these questions lies an unstated and often unquestioned assumption that these are new questions raised by a new century's problems. Indeed, as detailed below, President Bush's response to the attacks of September 11,2001, was premised on the conviction that existing international law did not contemplate and could not adequately respond to the novelty of the terrorist threat confronting the United States. Perhaps to a lesser extent, President Barack Obama has also accepted this assumption.

I challenge that assumption. Transnational terrorism is not a new problem. Puzzling about which law governs a state's response to organized force by non-state actors does not ask a new question. The novelty premise is not only false, it is a dangerous starting point for discussion of the applicability of international humanitarian law (also known as the law of armed conflict or the laws of war). Claiming newness where it does not exist diminishes the power of this body of law to achieve its twin goals: to limit armed conflicts to their shortest duration and fewest casualties. The assertion that we are at the cusp of what Hersch Lauterpacht called "the vanishing point of international law" 4 - that there is no applicable law to apply - is one step away from the hoary claim that law is silent in wartime (inter arma silent leges).

Although I argue that "[w] hat has been will be again," I do not claim that "there is nothing new under the sun." What is new is the changed relationship between state sovereignty and individual (human) rights, a change that affects how a state may lawfully confront a non-state actor in an armed conflict. ${ }^{6}$ Traditionally, states enjoyed absolute sovereignty and human beings were not subjects of international law. This view was radically altered by the twentieth century's experience of total warfare. No twenty-first century state possesses what nineteenth-century statesmen or international lawyers would recognize as absolute sovereignty. At the same time, individuals have acquired increasing rights as subjects (not merely

4. Hersch Lauterpacht, The Problem of the Revision of the Law of War, 29 BRIT. Y.B. INT'L L. 360, 382 (1952) ("If international law is, in some ways, at the vanishing point of law, the law of war is, perhaps even more conspicuously, at the vanishing point of international law.').

5. Ecclesiastes 1:9 (New International Version).

6. The terminology is not important. Individual rights is used hete to avoid confusion about substantive claims concerning human rights law. I mean only to distinguish between a focus on states versus a focus on individuals, without implying a position about the origin, scope, or content of those rights. 
objects) of international law. In other words, this novelty cuts in the opposite direction from the laisseqfaire claims to unregulated warfare that so appealed to President Bush's legal advisors, and which continue to nag at the edges of President Obama's counter-terrorism policies.

This Article develops these claims of continuity and change by examining the Martens Clause to the 1899 Hague Convention Respecting the Laws and Customs of War on Land. The Clause takes its name from Friedrich Fromhold von Martens (also known as Fyodor Fyodorovich Martens), the Russian Empire's extraordinary diplomat and international lawyer. Jean Pictet, the "main architect" of the Geneva Conventions of 1949, referred to the Clause as "the fruit of the genius of Friedrich von Martens."' Its author was a candidate for the Nobel Peace Prize9 and the recipient of honorary degrees from Cambridge, Edinburgh, Oxford, and Yale. ${ }^{10}$ The ICRC summarized the power of this short provision:

[T] he Martens clause, which itself applies independently of participation in the treaties containing it, states that the principles of international law apply in all armed conflicts, whether or not a particular case is provided for by treaty law, and whether or not the relevant treaty law binds as such the Parties to the conflict. ${ }^{11}$

This is not what the Martens Clause meant to Martens. In its author's day, Europe (especially Russia) confronted a surge of transnational terrorism that by every measure overshadowed the terrorism that darkened the start of our current century. Originally, the Martens Clause offered no protection whatsoever for these transnational terrorists. This was so even though the Clause sought to close the gaps to be found in the law of war by applying "principles of international law, ... the laws of humanity, and the requirements of the public conscience" when treaty law seemed absent

\footnotetext{
7. Press Release, Int'l Comm. of the Red Cross, Henry Dunant Medals Awarded at Red Cross Red Crescent Council of Delegates (Nov. 17, 2005), available at http://www.icrc.org/eng/resources/documents/ncws-release/2009-and-earlier/council-delegatesnews-171105.htm.

8. JEAN PICTIST, DEVELOPMINT AND PRINCIPLES OF INTERNATIONAL HUMANITARIAN LAW 60 (Martinus Nijhoff Publishers 1985).

9. Lauri Mälksoo, Friedrich Frombold von Martens (Fyodor Fyodorovich Martens) (1845-1909), in THE OXFORD HANDBOOK OF THE HISTORY OF INTERNATIONAL. LAW 1147, 1149 (Bardo Fassbender \& Anne Peters eds., 2012).

10. Vladimir Vasil'levich Pustogarov, OUR Martens: F.F. Martens, International, LAWYER AND ARCHITECT OF PEACE 46 (William Elliott Butler ed., trans., 2000) [hereinafter PUSTOGAROV, OUR MARTENS]. This may be the only biography written about Martens, perhaps due in part to the disappearance of his extensive diaries, which were kept in Soviet archives and were inaccessible until late in the perestroika period. Id. at ix-x (describing Butler's access to the diaries).

11. Bruno Zimmermann, Commentary to Article $I$, Protocol $I$, in COMMISNTARY ON THE ADDITIONAL PROTOCOIS OF 8 JUNE 1977 TO THE GENEVA CONVENTIONS OF 12 AUGUST 1949, at 39 (\$1 56) (Yres Sandoz et al., eds., ICRC 1987).
} 
or inapplicable. ${ }^{12}$ As will be discussed below, Martens's view of his Clause's applicability, although enlightened and innovative in 1899 , reflected the core assumptions of his day about sovereignty.

As one scholar observed, "[t]here is no denying that the way international relations were to develop in the decades following Martens' demise varied in many respects from the way Martens had anticipated or hoped for." 13 What changed? The relationship between individual rights and state sovereignty. The transformation of that relationship informs the answer to the questions that began this Article, even if it does not fully answer them.

Candor about the lack of conclusive answers reflects that this Article is also about the limits to the Martens Clause. The Clause has been the subject of a recent surge of interest as a source of argument in debates about new means and methods of warfare, such as cyber attacks and autonomous weapons systems. ${ }^{14}$ The history of the Martens Clause is generally omitted from these position papers. That history reminds us that the purpose of the clause was not to end debate, but to forestall the worst consequences for civilian populations and belligerents that would result if the parties assumed that a lack of tight-fitting treaty law meant carte blanche freedom to act, unconstrained by any law. The Martens Clause changed the baseline for such cases from one in which the parties perceived no obligations under international humanitarian law to one in which international humanitarian law could provide at least some basic protections. The Martens Clause moved the starting point for discussion from zero to some positive integer. That is sufficient cause for its continued celebration.

That baseline number has grown larger over the past century as state sovereignty has changed from an absolute to a relative value, as armed conflicts have increasingly involved non-state actors, and as international human tights law recast the individual as a subject of international law. States are no longer absolute sovereigns; international law demands respect for certain fundamental individual rights regardless of a sovereign's desire vel non to protect them. The emergence of a theory of one state's "responsibility to protect" individual rights against violation within another

12. Scott, supra note 1 , at 48 .

13. Arthur Eyffinger, Friedrich Martens: A Founding Father of the Hague Tradition (The Fourth Friedrich Martens Memorial Lecture), in 15 ESTONIAN NAT'L DEF. COL.L. PROC. 16 (Rain Livoja and Andres Saumets, eds., 2012), available at http://www.ksk.edu.ec/en/re-search/endc-proceedings-nr-15/.

14. See, e.g., Erki Kodar, Applying the Law of Armed Conflict to Cyber Attacks: From the Martens Clause to Additional Protocol $I$, in 15 ESTONIAN NAT'L DEF. COLL. PROC. supra note 13, at 107; BONNIE DOCHLRTY, HUMAN RIGHTS WATCH \& HARVARD INT'L HUMAN RIGHTS CIINIC, LOSING HumANITY: ThE CASE: AGAINST KILLER ROBOTS 24-26, 35-36 (2012) (explaining article and the topic it discusses). 
state points to the distance traveled from traditional views of sovereignty's empire. ${ }^{15}$

Indeed, if, as many argue, international human rights law is available and applicable at all times to protect all individuals, what present utility remains for the Martens Clause? ${ }^{16}$ It was intended as a filler of gaps in the law of armed conflict. Is there now any gap for which some body of international law, human rights or humanitarian, is not already available?

I seek to capture the change worked on this relationship with the peculiar phrase in the original Martens Clause from which this Article takes its title: civilians and belligerents live under a certain "protection and empire." In the twenty-first century, if not the nineteenth, this odd pairing emphasizes the century-long transformation of the relationship in international law between the recognition of human rights (protection) and the remaining privileges of state sovereignty (empire). The Martens Clause reflects a law of armed conflict that today demands both rights and duties of states fighting transnational non-state actors. These are rights and duties from which states cannot opt out by asserting that some aspect of an armed conflict is unprecedented or novel, or by claiming absolute sovereignty to act in the perceived interstices of incomplete treaty law from an earlier era.

In this way, the Martens Clause still has an important role to play, albeit in a world in which claims of absolute sovereignty have been pierced by a growing body of law that protects individuals regardless of the will of the state in which they reside. The broadly framed Martens Clause continues to be not only "an effective means of addressing the rapid evolution of military technology," as the International Court of Justice observed, but also a constant reminder of the evolving nature of armed struggles more generally. ${ }^{17}$ The Martens Clause also continues to stand for the proposition

15. Oona Hathaway, et al., Consent-Based Humanitarian Intervention: Giving Sovereign Responsibility Back to the Sovereign, 46 CORNEI.I. INT'L. L.J. 499, 529 (2013).

16. See, e.g., Office of the High Comm'r for Human Rights, International Legal Protection of Human Rights in Armed Conflict, 5-6, U.N. Doc. HR/PUB/11/01 (2011) ("Indeed, it is widely recognized nowadays by the international community that since human rights obligations derive from the recognition of inherent rights of all human beings and that these rights could be affected both in times of peace and in times of war, international human rights law continues to apply in situations of armed conflict. Moreover, nothing in human rights treaties indicates that they would not be applicable in times of armed conflict."). But see Legal Consequences of the Construction of a Wall in the Occupied Palestinian Territory, Advisory Opinion, 2004 I.C.J. 136, I 106 (July 9) ("As regards the relationship between international humanitarian law and human rights law, there are thus three possible situations: some rights may be exclusively matters of international humanitarian law; others may be exclusively matters of human rights law; yet others may be matters of both these branches of international law.').

17. See Legality of the Threat or Use of Nuclear Weapons, Advisory Opinion, 1996 I.C.J. 226, ๆ 78 (Jul. 8). 
that, although the development of new law tends to lag behind such change in the nature of armed conflict, that fact does not present the state a non liquet to exploit against its adversary.

Part I of this Article recounts the very anti-Martens Clause position that the United States embraced by asserting the novelty of a post-9/11 world. Part II rejects this assertion with an exploration of the transnational terrorism that besieged Europe and particularly the Russian Empire at the turn of the nineteenth century. Part III then provides a history of the Martens Clause, formulated at the 1899 Hague Peace Conference (which met, incidentally, at the suggestion of the Russian Czar). Part IV explains how the Martens Clause has changed from its origins, as a provision of international law that even its author considered irrelevant in the Russian Empire's fight with terrorists, to its present status as a provision that is inescapable wherever a sovereign state asserts itself to be fighting a transnational armed conflict with non-state actors.

\section{THE UNITED STATES AND TRANSNATIONAL TERRORISM}

On September 20, 2001, President George W. Bush informed a joint session of Congress that the attacks of September 11th were "an act of war against our country." 18 But the President asserted that the "war on terror"- his first use of this term-was different from past wars. ${ }^{19}$ His words resonated with earlier comments on the South Lawn of the White House, when the President had remarked on the novelty "of this conduct of this war against terrorism," saying: "This is a new kind of - a new kind of evil."20

This was not mere rhetoric. In a memo to the President four months later, then-White House Counsel Alberto Gonzales acknowledged that "[a]s you have said, the war against terrorism is a new kind of war." Gonzales concluded that "this new paradigm renders obsolete" some provisions of the Geneva Conventions, while others were now "quaint." 21

18. President George W. Bush, Address to a Joint Session of the 107th Congress (Sept. 20, 2001), available at http://georgewbush-whitehouse.archives.gov/infocus/bushrecord/documents/Selected_Speeches_George_W_Bush.pdf.

19. Id.

20. President George W. Bush, Remarks Upon Arrival at the South Lawn of the White House (Sept. 16, 2001), available at http://georgewbush-whitehouse.archives.gov $/ \mathrm{news} / \mathrm{rcleascs} / 20$ 01/09/20010916-2.html. This theme concluded the remarks as well: "That's why I say to the American people we've never seen this kind of evil before. But the evil-doers have never seen the American people in action before, either - and they're about to find out." Id.

21. Memorandum from Attorney General Alberto R. Gonzales to President George W. Bush, Discussion re: Application of the Geneva Convention on Prisoners of War to the Conflict with al Qaeda and the Taliban (Jan. 25, 2002), available at http://www2.gwu.edu/ nsarchiv/NSAEBB/NSAEBB127/02.01.25.pdf. Four years later, President Bush declared that provisions of 
The reason was that "this is a new type of warfare-one not contemplated in 1949 when the GPW [Geneva Convention Relative to the Treatment of Prisoners of War] was framed-and requires a new approach in our actions towards captured terrorists." 22

In fact, the administration's view of the inapplicability of the Geneva Conventions extended much further than a few of its provisions. Administration officials argued that the Geneva Conventions applied only to instances of armed conflict between nation-states or, with much more limited effect, to conflicts within a state fought between that state and non-state insurgents or rebels. ${ }^{23}$ Since the conflict between the United States and al-Qaeda fit neither description, no governing legal regime was triggered by the American use of force (although, it was claimed, international law permitted the use of force in response to al-Qaeda's attacks). ${ }^{24}$ President Bush therefore concluded that "[a]s a matter of policy"- not as a matter of law-the United States would treat detainees humanely and, "to the extent appropriate and consistent with military necessity, in a manner consistent with the principles of Geneva."25

The limitation "consistent with military necessity" effectively rendered the otherwise generous policy of broad compliance with international humanitarian law null and void. The point of the Geneva Conventions was to provide certain rights that were not subject to easy derogation on grounds of necessity or otherwise. But America claimed to be fighting something new to public international law. Al-Qaeda and Taliban fighters

Common Article 3 of the Geneva Conventions were "vague and undefined." George W. Bush, Address on the Creation of Military Commissions to Try Suspected Terrorists (September 6, 2006), available at http://georgewbush-whitehouse.archives.gov/infocus/bushrecord/documents/Selected_Speeches_George_W_Bush.pdf.

22. Gonzales, supra note 21 , at 3 .

23. Memorandum from George W. Bush to the Vice President, the Secretary of State, the Secretary of Defense, the Attorney General, the Chief of State to the President, the Director of Central Intelligence, the Assistant to the President for National Security Affairs, and the Chairman of the Joint Chiefs of Staff, Humane Treatment of Taliban and al Qaeda Detainees (Feb. 7, 2002), available at http://www.pegc.us/archive/White_House/bush_memo_20020207_ed.pdf.

24. Id. ("I determine that the Taliban detainees are unlawful combatants and, therefore, do not qualify as prisoners of war under Article 4 of Geneva. I note that, because Geneva does not apply to our conflict with al Qaeda, al Qaeda detainees also do not qualify as prisoners of war.'); see also Brief for Respondents at 48, Hamdan v. Rumsfeld, 548 U.S. 557 (2006) (No. 05-184) ("As the President determined, because the conflict between the United States and al Qaeda has taken place and is ongoing in several countrics, the conflict is 'of an international character,' and Article 3 is thus inapplicable.").

25. Memorandum from George W. Bush to the Vice President, et al. supra note 23, at 13 . Perhaps implicit in this discussion of the applicability of international humanitarian law to such conflicts is the problem of reciprocity. For an excellent discussion of the issue with special regard to contemporary conflicts with non-state actors, see René Provost, Asymmetrical Reciprocity and Compliance with the lans of War, in MODERN WARFARE: ARMED Groups, Private Militaries, HUMANITARIAN ORGANI7.ATIONS, AND THE LAW 17, 17-42 (Benjamin Perrin ed., 2012). 
were "unlawful combatants" in a global "war on terrorism" that did not fit within the conventional categories of armed conflicts. ${ }^{26}$ According to the United States Government, such a war could be fought free of any constraints imposed by the Geneva Conventions. ${ }^{27}$

The ICRC rejected this approach, just as it rejected this terminology. ${ }^{28}$ The ICRC argued that a case-by-case assessment of violence around the globe would lead to one of three classifications. ${ }^{29}$ The first and clearest case in which the Geneva Conventions applied was an armed conflict of

26. Although the terms "unlawful combatant" and "enemy combatant" were not new, see Kenneth Watkin, Warriors Without Rights? Combatants, Unprivileged Belligerents, and the Struggle Over Legitimacy, 2 Program ON HUMANITARIAN POL'Y AND CONFI.ICT RES., HARV. UNIV., OCCASIONAL. PAPER SERIISS 5 n.10, $65 \quad$ (2005), available http://wwwhpcrresearch.org/sites/default/files/publications/OccasionalPaper2.pdf; the concept of a "global war on terror," or "GWOT" in Pentagon patois, was new to this discussion. DEPARTMENT OF DEFENSE Directive: 2310.01E, ENClosure 2 (Sept. 5, 2006), in INT'L AND OPERATIONA. LAW DEP'T, U.S. ARMY JUDGE ADVOCATE GEN'S LEGal CTR. AND SCH, LAW OF ARMED CONFliCT DOCUMENTARY SUPPLEMENT 407 (Wm. J. Johnson, ed., 2013), available at http://www.loc.gov/rr/frd/Military_Law/pdf/LOAC-Documentary-Supplement-2013.pdf

("Unlawful enemy combatants are persons not entitled to combatant immunity, who engage in acts against the United States or its coalition partners in violation of the laws and customs of war during an armed conflict. For purposes of the war on terrorism, the term Unlawful Enemy Combatant is defined to include, but is not limited to, an individual who is or was part of or supporting Taliban or al-Qaeda forces or associated forces that are engaged in hostilities against the United States or its coalition partners.').

27. Even rights previously accepted as reflective of customary international law, such as the "fundamental guarantees" of Article 75 of Additional Protocol I were subject to reinterpretation. See Marko Milanovic, lessons for Human Rights and Humanitarian Law in the War on Terror: Comparing Hamdan and the Israeli Targeted Killings, 89 INT'J. RE.V. RED CROSS 373, 387 (2007) (noting that although two previous U.S. State Department Legal Advisors had confirmed its customary international law status, "the current US administration has regrettably cast even this point into doubt, and its present Legal Adviser has stated that the administration is 'looking at' whether Article 75 guarantees are applicable in the 'war on terror'.').

28. Gabor Rona, Legal Adviser, Int'l Comm. of the Red Cross, Presentation at Workshop on the Protection of Human Rights While Countering Terrorism: When is a War Not a War? The Proper Role of the Law of Armed Conflict in the "Global War on Terror"(Mar. 16, 2004), available at http://www.icrc.org/eng/resources/documents/statement/5xcmnj.htm ("The phrase 'war on terror' is a rhetorical device having no legal significance."); INT'L COMM. OF THE RED CROSS, 30IC/07/8.4, INTERNATIONAL. HUMANITARIAN LAW AND THE CHALLENGES OF CONTEMPORARY ARMED CONFLICTS: REPORT PREPARID FOR THE 30TH INTERNATIONAL CONFERENCE OF THE RED CROSS AND RED CRESCENT 8 (2007) [hereinafter ICRC 30TH CONFERENCE REPORT] available at https://www.icrc.org/eng/assets/files/other/ihl-challenges-30th-international-conference-eng.pdf (describing IHL concerning status of persons and observing "IHL treaties contain no explicit reference to 'unlawful combatants."'); INT'L COMM. OF THE RED CROSS, 31IC/11/5.1.2, INTERNATIONAL. HUMANITARIAN LAW AND THE CHALLIENGES OF CONTEMPORARY ARMED CONFLICTS: REPORT PREPARED FOR THE 31ST INTERNATIONAL CONFERENCE OF THE RED CROSS AND RED CRESCENT 10 (2011) Thereinafter ICRC 31ST CONFERENCE REPORT], https://www.icrc.org/eng/assets/filcs/red-cross-crescent-movement/31 st-international-

conference/31-int-conference-ihl-challenges-rcport-11-5-1-2-en.pdf ("It should be reiterated that the ICRC does not share the view that a conflict of global dimensions is or has been taking place.").

29. ICRC 31ST CONFERENCE REPORT, supra note 28, at 7-11. 
any intensity between two states (a "Common Article 2" conflict, so named for the identically numbered articles of all four Geneva Conventions). ${ }^{30}$ In the second place, international humanitarian law also applied in more limited fashion to conflicts "not of an international character" (i.e. a "Common Article 3" conflict) if the parties were sufficiently organized and the violence between them had reached a sufficient level of intensity.3. If, thirdly, either the criteria of organization or intensity were not met, that did not mean that an unregulated armed conflict was permitted. Rather, an armed conflict simply could not be said to occur. In such a case, neither party could invoke the authorities or claim the protection of the law of armed conflict. Instead, domestic law and international human right law applied to any use of force. In any event, the ICRC insisted that this treaty-based nomenclature should not obscure the fact that considerable customary international humanitarian law applied to armed conflict regardless of its inter-state nature. ${ }^{32}$ As a matter of law, the ICRC observed, "there can be no wars in which one side has all the rights and the other has none." 33

The Supreme Court of the United States also rejected the Bush Administration's view. ${ }^{34}$ But the Court's decision came five years after the government operationalized its original legal position. The interim result, as Geoff Corn observed, was that the legal framework that had long

30. Article 2 of each of the four Geneva Conventions of August 12, 1949 (Common Article 3) states "the present Convention shall apply to all cases of declared war or of any other armed conflict which may arise between two or more of the High Contracting Parties, even if the state of war is not recognized by one of them." Geneva Convention for the Amelioration of the Condition of the Wounded and Sick in Armed Forces in the Field art. 2, Aug. 12, 1949, 75 U.N.T.S. 31 ?hereinafter Geneva Convention 1]; Geneva Convention for the Amelioration of the Condition of Wounded, Sick and Shipwrecked Members of Armed Forces at Sea art. 2, Aug. 12, 1949, 75 U.N.T.S. 85 Thereinafter Geneva Convention II]; Geneva Convention Relative to the Treatment of Prisoners of War art. 2, Aug. 12, 1949, 75 U.N.T.S 135 [hereinafter Geneva Convention III]; Geneva Convention Relative to the Protection of Civilian Persons in Time of War art. 2, Aug. 12, 1949, 75 U.N.T.S. 287 [hereinafter Geneva Convention IVI. As the official commentary makes clear, "It makes no difference how long the conflict lasts, or how much slaughter takes place. The respect due to the human person as such is not measured by the number of victims." INT'L COMM. OF THE RFD CROSS, COMMENTARY: IV Geneva CONVENTION RELATIVE to THE PROTECTION OF CIVILIAN PERSONS IN TIME OF WAR 20-21 (Jean S. Pictet ed., 1958).

31. Article 3 of each of the four Geneva Conventions of August 12, 1949 states that "[i]n the case of armed conflict not of an international character occurring in the territory of one of the High Contracting Parties, each Party to the conflict shall be bound to apply, as a minimum, the following provisions." Geneva Convention I, supra note 30, at art. 3; Geneva Convention II, supra note 30, at art. 3; Geneva Convention III, supra note 30, at art. 3; Geneva Convention IV, supra note 30, at art. 3.

32. ICRC 31ST CONFERENCE REPORT, supra note 28, at 12 ("As a matter of customary law, the basic IHL principles and rules governing the conduct of hostilities are, with very few exceptions, essentially identical regardless of the conflict classification.").

33. ICRC 28TH CONFERENCE REPORT, supra note 3 , at 19.

34. Hamdan v. Rumsfeld, 548 U.S. 557, 630 (2006). 
governed the American interpretation of the law of armed conflict was "thrown into disarray." 35 During the first and most intense stage of the war on terror, the United States held to the view that the jus ad bellum-the law governing the right to use force-provided legal justification for the United States to respond with military force, but the jus in bello- the law governing how military force may be used-did not provide any rights to those against whom that force would be applied. ${ }^{36}$

President Obama has also stated that the United States is at war- "a different kind of war"-with non-state actors: al-Qaeda, the Taliban, and their associated forces. 37 The Obama Administration has asserted international legal authority to engage in an armed conflict with al-Qaeda based on the United States's right to self-defense. ${ }^{38}$ But this assertion of a basis for action in international law does not always align with the existing understandings of those legal foundations by other states or the ICRC. ${ }^{39}$

For example, while President Obama has indicated the approaching end to the armed conflict in Afghanistan, he has also said that lethal action may also be taken "outside of warzones," although "[b]eyond the Afghan

35. Geoffry S. Corn, What Lan Applies to the War on Terror?, in THE WAR ON TERROR AND THE LAWS OF WAR: A MILITARY PIERSPECTIVE 1 (Michael W. Lewis et al. eds., 2009).

36. This was not a necessary interpretation. Much closer in time to the drafting of the 1949 Geneva Conventions, the preeminent international law scholar Hersch Lauterpacht observed, "The Convention imposes certain minimum obligations of humane treatment even in armed conflicts which are not of an international character and even if the parties to the conflict, which may not be states, are not parties to the Convention-an interesting example of obligations being imposed upon entities which are not normally subjects of international law." Lauterpacht, supra note 4, at 361 (citing Common Art. 3).

37. President Barack Obama, Address at the National Defense University (May 23, 2013), http://www.whitchouse.gov/the-press-officc/2013/05/23/remarks-president-barack-obama ("[O]n September 11 th 2001, we were shaken out of complacency. Thousands were taken from us, as clouds of fire, metal and ash descended upon a sun-filled morning. This was a different kind of war. No armies came to our shores, and our military was not the principal target. Instead, a group of terrorists came to kill as many civilians as they could ... Beyond Afghanistan, we must define our effort not as a boundless 'global war on terror'-but rather as a series of persistent, targeted efforts to dismantle specific networks of violent extremists that threaten America .... Under domestic law, and international law, the United States is at war with al Qaeda, the Taliban, and their associated forces. We are at war with an organization that right now would kill as many Americans as they could if we did not stop them first. So this is a just war - a war waged proportionally, in last resort, and in self-defense.").

38. Id.

39. John B. Bellinger III, Observations on the 150th Anniversary of the ICRC, 94 INT'L REV. RED Cross 1223, 1224-25 (2012) ("The Bush Administration, of course, was and continues to be criticised for not applying the privileges of the Third or Fourth Conventions to members of $\mathrm{Al}$ Qaeda and the Taliban as a matter of law. The Bush Administration did apply most Geneva provisions as a matter of policy. It is important to emphasize that the Obama Administration has not changed this legal position and has not treated Al Qaeda and Taliban detainces as prisoners of war or protected civilians. Nor has the Obama Administration concluded that Article 75 of Additional Protocol I applies to $\mathrm{Al}$ Qaeda and the Taliban detainees.'). 
theater, we only target al Qaeda and its associated forces." 40 Because alQaeda "does not follow a traditional command structure, wear uniforms, carry its arms openly, or mass its troops at the borders of the nations it attacks," the Administration has also asserted the right to do so "without doing a separate self-defense analysis each time," without "being restricted solely to "hot' battlefields like Afghanistan," and based on a "broadened" notion of what constitutes an imminent attack. ${ }^{41}$ Remarks by the President and his advisors make clear that this decision-making is also premised on the novelty of this war. ${ }^{42}$

Likewise, while the President has announced his intention to "bring law of war detention to an end," he notes that when suspected terrorists are captured, "we decide whether to try him in a civilian court or a Military Commission." 43 How that decision should be made seems to be primarily results-driven: "In choosing between our federal courts and military commissions in any given case, this Administration will remain focused on one thing- the most effective way to keep that terrorist behind bars." 44

Thus, the Obama Administration "has expanded the ambit of its selfcongratulatory but unspecified application of the law of armed conflict as a matter of policy. This takes the form of claims that a U.S. policy or law is 'informed by' or 'draws on' the laws of war, but never explaining in what way." 45 If, as seems likely, the national security strategy of the United

40. Obama, supra note 37.

41. John O. Brennan, Assistant to the President for Homeland Sec. and Countertertorism, Remarks at Harvard Law School: Strengthening our Security by $\Lambda$ dhering to our Values and Laws (Scpt. 16, 2011), http://www.whitehouse.gov/the-press-office/2011/09/16/remarks-john-o-brennan-strengthening-our-security-adhering-our-values-an.

42. Id. ("We are finding increasing recognition in the international community that a more flexible understanding of 'imminence' may be appropriate when dealing with terrorist groups, in part because threats posed by non-state actors do not present themselves in the ways that evidenced imminence in more traditional conflicts ... Over time, an increasing number of our international counterterrorism partners have begun to recognize that the traditional conception of what constitutes an 'imminent' attack should be broadened in light of the modern-day capabilities, techniques, and technological innovations of terrorist organizations.").

43. Obama, supra note 37. See also Memorandum from Brad Wiegmann and Colonel Mark Martins to the Attorney General and the Secretary of Defense, Detention Policy Task Force 4-5 (Jul. 20, 2009) available at http://fas.org/irp/agency/doj/detention072009.pdf.

44. Brennan, supra note 41.

45. Chris Jenks, The King is Dead! Long Live the King! Why the U.S. is Content Applying Law of War Treaties as a Matter of Policy (June 2014) (unpublished working paper) (on file with author) (citing such ambiguous language in Executive Order 13,567, signed on Mar. 7, 2011). See also U.S. DEP'T OF JUSTICE, 100 DAY PROGRESS REPORT (2009) available at http://www.justice.gov/sites/default/files/ag/legacy/2009/04/29/progress-report.pdf ("TT]he Department worked with other agencies and departments to develop a new standard for the government's authority to hold Guantanamo detainces . . . [T] his standard does not rely on the President's authority as Commander in Chief independent of Congress's specific authorization. Instead, it draws on the international laws of war to inform the statutory authority conferred by 
States will continue to rely on legal authority drawn from the law of armed conflict, these ambiguities are disconcerting at the very least. Legal authority without legal constraint is a dangerous combination under any circumstance. Considering the extraordinary authority that the law of armed conflict provides, the need for clarity concerning its limits will remain both important and urgent. As Geoff Corn observed, using a common shorthand for the law of armed conflict, this was the essential post-9/11 problem: "invocation of the LOAC authority without a counterbalance of LOAC obligation was inconsistent with the historic purpose of the [Geneva Convention] law." 46

Before considering the placement of those baseline limits in fighting terrorism tomorrow, Part II of this Article considers a struggle with transnational terrorists in a past lacking any international legal baseline at all.

\section{THE RusSiAn EMPIRE AND TRANSNATIONAL TERRORISM}

The Russian revolutions of 1917 were preceded by waves of violence and futile attempts of the Russian state to stop it. The terrorists were transnational non-state actors if ever there were any. In fact, one of the venues considered for the 1899 Peace Conference, Berne, was rejected because (in the words of the head of the American delegation to the Conference, Andrew Dickson White): "The number of anarchists and nihilists who had taken refuge there, and the murder of the Empress of Austria by one of them shortly before, at Geneva, in broad daylight, had thrown discredit over the ability of the Swiss Government to guarantee safety to the conference." 47

The leaders of various terrorist groups could be found in the British Library in London, the boulevards of Paris and Berlin, and, of course, throughout the expanse of the Russian Empire. ${ }^{48}$ Lenin, for example, left

Congress in the Authorization for the Use of Military Force, which Congress passed in September 2001.'); Harold Koh, Legal Adviser, U.S. Dep't of State, Keynote Speech at the Annual Meeting of the American Society of International Law: The Obama $\Lambda$ dministration and International Law (Mar. 25,2010 ) available at http://www.statc.gov/s/l/releases/remarks/139119.htm ("NW]ith regard to individuals detained at Guantanamo, we explained in a March 13, 2009 habeas filing before the DC federal court-and repeatedly in habeas cases since-that we are resting our detention authority on a domestic statute - the 2001 Authorization for Use of Military Force (AUMF) - as informed by the principles of the laws of war.).

46. Corn, supra note 35 , at 19.

47. Arthur Eyffinger, THE 1899 Hague PeAce Conference 40 (1999) (quoting the autobiography of A.D. White).

48. D.S. MIRSKY, RUSSIA: A SOCLAL HISTORY 260-62 (1952) (noting that " $[\mathrm{t}]$ he first cells of the revolutionary movement were founded abroad..." and that their headquarters were later to be found "in London, in Paris, or in Switzerland, where large colonies of Russian émigrés grew up and 
Russia in 1900 for Zurich, Munich, and London after finishing his criminal term of exile to Siberia. ${ }^{49} \mathrm{He}$ returned to St. Petersburg in 1905 (though too late to join the 1905 Revolution) and again from Zurich in 1917, to renamed Petrograd, on a specially arranged German train. ${ }^{50}$ As flowed terrorists, so too did the means of terrorism move across Europe: different groups collaborated "[u]sing their connections with arms dealers abroad, particularly in Belgium and England,... in the complicated process of purchasing and transporting arms and explosives materials into Russia[.]" 51 Funding for these cross-border arms shipments and bombmaking laboratories led to enterprising collaborations not only between different national movements but with various criminal groups..$^{52}$

There were so many terrorist organizations of various political stripes in the decades preceding the February and October 1917 Russian revolutions that it is hard to keep them all straight: populists, anarchists, and nihilists filled the ranks of "Land and Liberty" (Zemlya i Volya) (founded 1876), while the more violently minded among them split to form "The People's Will" (Narodnaya volya) (founded 1879). Marxists could become "professional revolutionaries" stocking Lenin's Bolshevik Social Democrats (SD) (1903), or members of the "Combat Organization" of the Socialist Revolutionaries (SR) (1902). 53 The ideologies of nineteenth century Russian terrorists varied as greatly as their social class-from idealistic "déclassé gentry" youths; to radicalized emerging proletariat; to upstart, uneducated peasants, and (increasingly) police infiltrators and agents provocateurs. ${ }^{54} \mathrm{But}$ by the late $1880 \mathrm{~s}$, the strongest movements shared several traits in common: they were transnational, messianic, and bent on the violent destruction of the imperial Russian government and revolutionary transformation of the state. 55 These groups saw themselves as existential threats to the Russian Empire even if, after their varying

survived till 1917."). The founding congresses of the Russian Social Democratic Workers' Party were held in Minsk (1898), Brussels and London (in 1903), where the Bolsheviks seized control. Reginald E. Zelnik, Russian Workers and Revolution, in THE CAMBridge HISTORY OF RUSSIA, VOL. II 628 (Dominic Lieven ed., 2006).

49. ROBERT SERVICE, LENIN: A BIOGRAPHY 109, 129, 175 (2000).

50. Id. at 253-63.

51. ANNA GEIFMAN, ThOU Shalt Kill: REvolutionary TERrorism IN RUSSIA, 1894-1917 187 (1993).

52. Id. at $190-92$.

53. HANS ROGGER, RUSSIA IN THE AGE OF MODERNISATION AND RIEVOLUTION, 1881-1917, 132-62 (1983); THE BLACKWELL. ENCYCLOPEDIA OF THE RUSSIAN REVOLUTION passim (Harold Shukman ed., 1988) [hereinafter Bl.ACKWELL].

54. MIRSKY, sipra note 48, at 260-64. RICHARD PIPIS, RUSSIA UNDER THE OLD REGIME $270-$ 75 (1992). GEIFMAN, supra note 51 , at 11 .

55. Zelnik, supra note 48 , at $623-24$. 
contributions toward that goal, only the Bolsheviks survived to claim the mantle of destructor.

Terrorist cells were carefully organized for maximum tactical advantage and minimum risk of infiltration. Cell members often knew no more than one person from another cell. At the same time, different terrorist groups active in Russia-whose acrimonious spokesmen outside of Russia often criticized each other as much as the mutually despised regime-could put aside their ideological differences to collaborate. As the chief of one group asked another: "Why can't we work together? As far as I'm concerned, there are no obstacles. It makes no difference to me whether you are a Maximalist, an anarchist, or a Socialist-Revolutionary. We are both terrorists. Let us combine our organizations in the interest of terror." 56

In fact, the transnational terrorist threat even invaded popular literature, in Russia and abroad. Ivan Turgenev's Fatbers and Sons captures the rise of a radicalized new generation, while Fyodor Dostoyevsky's The Possessed explores the mind of a radical nihilist. (Dostoyevsky allegedly once confessed that "he would have been incapable of turning over to the police hypothetical terrorists overheard talking about a bomb planted by them in the Winter Palace.') ${ }^{57}$ Joseph Conrad's The Secret Agent, published in 1907 but set in 1886, revolves around a plot to blow up the Greenwich Observatory in London. (The idea probably came to Conrad from an actual event: In 1894, a young French anarchist named Martial Bourdin attempted to blow up the Observatory. $)^{58}$ The novel imagines a conspiracy led by the first secretary of a foreign (presumably Russian) embassy in London, who manipulates an agent provocateur embedded in an anarchist group. The diplomat's goal is to jolt an international conference into a more aggressive stance against terrorism: "Its deliberations upon international action for the suppression of political crime don't seem to get anywhere. England lags. This country is absurd with its sentimental regard for individual liberty." 59 His means are the terrorists themselves and his explanation for the seemingly senseless destruction of a purely scientific outpost is remarkably contemporary:

This is what you should try for. An attempt upon a crowned head or on a president is sensational enough in a way, but not so much as it used to be. It has entered into the general conception of the

56. GEIFMAN, supra note 51, at 183 (quoting Boris Savinkov, head of the SR Combat Organization, to Mikhail Sokolov, leader of the Maximalists, an SR offshoot).

57. PIPES, supra note 54, at 275.

58. Royal Museums Greenwich, Propaganda by Deed: The Greenwich Observatory Bomb of 1894, undated, http://www.nmm.ac.uk/server/show/conWebDoc. 413.

59. JOSEPh CONRAD, ThE SECret AGEnt 29 (Oxford World's Classics 1998) (1907). 
existence of all chiefs of state. It's almost conventional-especially since so many presidents have been assassinated .... But what is one to say to an act of destructive ferocity so absurd as to be incomprehensible, inexplicable, almost unthinkable; in fact, mad? Madness alone is truly terrifying, inasmuch as you cannot placate it either by threats, persuasion, or bribes. ${ }^{60}$

By any measure, these fin-de-siècle terrorists were more successful at their stated goals than al-Qaeda has been with its objectives. By the time of the Second Hague Peace Conference in mid-1907, these terrorists had succeeded (on the fifth attempt) in assassinating Czar Alexander II. ${ }^{61}$ Terrorists also killed his son, the Grand Duke. ${ }^{62}$ One of the first terrorist attacks, a daylight knifing in St. Petersburg in 1878, took the life of the Chief of the Gendarmes. ${ }^{63}$ Other assassinations included the last Czar's Education Minister, ${ }^{64}$ two Interior Ministers, ${ }^{65}$ his Prime Minister, ${ }^{66}$ and well over a thousand other government officials. ${ }^{67}$ Thousands of civilians were killed or wounded in the course of this campaign. ${ }^{68}$ An early attempt to assassinate Prime Minister Stolypin in August 1906 by a suicide-bomber faction of the Socialist Revolutionary Party failed to kill the prime minister, but succeeded in killing twenty-seven others and injuring sixty, including Stolypin's children. ${ }^{69}$ During 1907, terrorist violence averaged eighteen casualties a day. ${ }^{70}$ In the two years following the second Hague Peace Conference, from January 1908 to May 1910, 732 government

60. Id. at 31,33 .

61. Alexander II was killed by a bomb thrown by a member of Narodnaya volya in 1881. Other attempts-including gunshots fired at his carriage and the bombing of his train and the Winter Palace-occurred in 1879 and 1880, to which may also be added an early, separate attempt in 1866 .

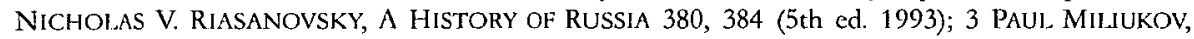
HISTORY OF RUSSIA 71, 82-84, 90-91 (1969).

62. Socialist Revolutionary member I.P Kalyaev assassinated Grand Duke Sergei Aleksandrovich in February 1905. BL.ACKWELL, supra note 53, at 86. .

63. PIPES, supra note 54, at 299.

64. Socialist Revolutionary member P. V. Karpovich assassinated the Minister of Education, N. P. Bogolepov, in February 1901. BI.ACKWELL, supra note 53, at 86; GEIFMAN, supra note 51, at 18.

65. Socialist Revolutionary member S. V. Balmashev assassinated Minister of the Interior, D. S. Sipyyagin, in July 1904. Similarly, Sazonov, another member of the Socialist Revolutionary, assassinated V. K. von Plehve, another Minister of the Interior, in July 1904. BL.ACKWELL, supra note 53 , at 86 .

66. Prime Minister Stolypin was shot and killed in September 1911.

67. Between February 1905 and May 1906, Jonathan Daly approximates 1,075 state officials killed or wounded. Jonathan Daly, Police and Revolutionaries, in THE CAMBRIDGE HISTORY OF RUSSIA, VOL. 2 supra note 48 , at 647 . In 1906, he states that "as many as" 1,126 government officials were killed, 1,506 wounded. $I d$. at 648 .

68. GEIFMAN, supra note 51 , at 264 n.59.

69. BLACKWELL, supra note 53, at 87; GEIFMAN, supra note 51, at 74 .

70. GEIFMAN, supra note 51 , at 21 . 
officials and 3,051 citizens were killed, and 4,000 wounded, in terrorist attacks. ${ }^{71}$ These figures do not include robberies and other acts of destructive violence directed at property, transport, and state infrastructure, nor does the listing of top targets for assassination convey the much larger number of terrorist attacks that occurred outside the imperial capital and in the imperial periphery. As Anna Geifman described the rising tide of less discriminating violence after the 1905 Revolution:

Of the 671 employees of the Ministry of the Interior killed or injured by terrorists between October of 1905 and the end of April 1906, only 13 held high administrative positions, while the other 658 were city policemen, coachmen, and security personnel. It became especially common for the new breed of professional terrorist to shoot or toss bombs into passing military and Cossack units, or their barracks, without provocation. In general, the wearing of any uniform was sufficient to qualify an individual as a potential candidate for a terrorist bullet or for other methods of attack widely adopted after 1905.72

As the imperial government felt ever more besieged, it relied increasingly on its military. The civilian casualties on "Bloody Sunday" 1905 were caused by a cavalry charge followed by eight volleys into the crowd from a rifle regiment, neither of which were considered to be unusual methods of crowd dispersal. ${ }^{73}$ As one eminent historian of Russia described the regime, "as far as terrorist activities were concerned, Russia was to be treated by its government as if it were occupied enemy territory. ... Once a year, the Chief of Gendarmes submitted to the emperor a report on campaigns his organization had waged against subversives which read somewhat like a summary of military operations." 74

A year before Czar Alexander II's death, Russia's special police forcethe so-called Third Department-was subsumed into the Ministry of the Interior and its Gendarmerie placed under the control of the Ministry of

71. Douglas Smith, Former People: The Final, Days of the Russian ARistocracy 58 (2012).

72. GEIFMAN, supra note 51 , at 40 (footnotes omitted).

73. SiDNEY HARCAVE, FIRST BLOOD: THI RUSSIAN REVOLUTION OF 1905 86-91 (1964) ("It was standard procedure for mounted police and cavalry (usually Cossacks), free to use nagaikas and the flats of their sabers, to ride down recalcitrant crowds and force them to disperse. What if these measures failed? Commanding officers could order their men to fire warning volleys; and if these did not bring compliance, they could then order that the firing be directed into the crowds."). See also ABRAHAM ASCHER, THE REVOI.UTION OF 1905: RUSSIA IN DISARRAY 91 (1988) ("Troops fired indiscriminately, hitting people who were trying to escape as well as innocent bystanders."). Official (and likely low) figures placed the death toll at 130, 299 injured. Id. Others put the death toll much higher, estimating " 800 dead and many more wounded." BLACKWELL, supra note 53 , at 105.

74. PIPES, supra note 54 , at $299,301$. 
War. 75 After his death, so-called temporary regulations systematized piecemeal legislation under which military field courts could try civilians for select state crimes in closed proceedings conducted not just under military law, but the military law applicable in time of war (while, at the same time, a soldier or officer would be tried under the military law applicable in time of peace!). ${ }^{76}$ Between July 1906 and April 1907, these courts "were obliged to pass judgment in no more than two days and to carry out the sentence (usually death) within one day"; they were responsible for the execution of "as many as 1,000 alleged terrorists." 77

Then, unlike now, no one debated whether these attacks rose to such a degree that they could be said to have triggered the law of armed conflict. Decades would pass before anyone would seriously consider the idea that conflicts "not of an international character" could even be the subject of international law. But if today's law of armed conflict applied in the final years of the Romanov dynasty, what result? Considering the duration and intensity of these hostilities, could it be said (however anachronistically) that Russia was in an armed conflict with one or more organized and armed non-state actors? That these fighters were civilians directly participating in hostilities?

\section{THE MARTENS ClaUSE}

Consider now the development of public international law in the context of the increasingly mechanized violence of late nineteenth-century war. Terrible new armaments like expanding bullets, asphyxiating gas, and war balloons multiplied the carnage on European battlefields. The Battle of Solferino in 1859, witnessed by one of the future founders of the Red Cross, motivated individuals and nation-states alike to create new institutions and bodies of law to regulate the effects of these changes. ${ }^{78}$

Not only had the nineteenth century ushered in new weapons, it had grossly expanded the ranks of fighters. The French Revolution created the first state to raise a modern army through universal conscription: "Tout Français est soldat et se doit à la défense de la patrie." ${ }^{.79}$ Until then, most

75. Daly, supra note 67, at 637-39.

76. William C. Fuller, Jr., Civilians in Russian Military Courts, 1881-1904, 41 RuSsIAN REv. 288, 292 (1982). Of 73 trials of members of the People's Will terrorist organization conducted in the 1880s, 42 were held in military courts. Id. at 293. See also PIPES, supra note 54, at 299, 305.

77. Daly, supra note 67, at 648. During the period of use of summary military courts-martial, August 1906 to April 1907, more than 1,000 people were shot or hanged as revolutionaries, terrorists, or expropriators. GEIFMAN, supra note 51 , at 227.

78. J. Henry Dunant, A Memory of SolfFerino 9 (American National Red Cross 1959) (1862).

79. "Every Frenchman is a soldier and has the duty to defend his country." (Author's 
of the European Great Powers relied primarily on professional mercenaries (Russia, as always, was an exception: between 1705 and 1874, the czars relied on peasants drafted for periods ranging from life to 25 years of service [nearly the same thing]; in 1874, universal military conscription regardless of class was initiated.) ${ }^{80}$ As this concept spread through Europe, larger armies expanded war's effects further and further beyond the set-piece battlefields of the past. ${ }^{81}$

The 1899 Hague Peace Conference was not the first international effort seeking to moderate these forces. Earlier attempts at international agreement achieved varying success. In 1864, the Geneva Convention sought to ensure safe access to the battlefield for neutral medics to provide relief to all wounded belligerents. In 1868, Czar Alexander II's St. Petersburg Declaration sought the prohibition of small-sized exploding bullets (which had little military value but greatly increased suffering), ${ }^{82}$ Fulminating ammunition would eventually be rendered obsolete by inevitable technological progress. But the Russians, who achieved the initial breakthrough and feared its proliferation and use against their own soldiers, led the drive for its abolition. ${ }^{83}$ The Declaration established an important principle: even belligerents fully privileged to fight under the laws of war do not enjoy unlimited rights to do so. ${ }^{84}$ Another attempt in Brussels in 1874, also called by the Czar, ended without agreement. ${ }^{85}$ The Brussels Declaration itself "drew its life and spirit" from the Lieber Code adopted by President Lincoln in $1863 .{ }^{86}$ Perhaps a more successful effort, and certainly a more lasting one than these, was the establishment in 1873 of the Institut de Droit international in Ghent. ${ }^{87}$ These all helped form a

translation). See Art. 1, Loi relative au mode de formation de l'armée de terre du 19 Fructidor, an VI de la République une et indivisible (loi Jourdan of Sept. 5, 1798), BULI.ETIN DES LOIS DE I.A RÉPUBIIQUE FRANÇAISE (NO. 223) (1798), http://gallica.bnf.fr/ark:/12148/bpt6k56398t/f492.image

80. William C. Fuller, Jr., The Imperial Army, in The CAMBridge History OF Russia, VOl. 2 supra note 48, at 532, 544; see also H.T. Willetts, The Imperial Armed Forces, in THE CAMBRIDGE ENCYCLOPEDIA OF RUSSIA AND THE FORMER SOVIET UNION 508 (Archic Brown et al. eds., 1994)

81. EYFFINGER, supra note 47, at 258.

82. Scott, supra note 1 , at xv.

83. See INT'L COMM. Of THE Red Cross, DeClaration Renouncing the USE, in Time of WAR, OF EXPLOSIVE PROJECTILES UNDER 400 GRAMMISS WEIGHT (1868), https://www.icrc.org/applic/ihl/ihl.nsf/52d68d14de6160e0c12563da005fdb1b/dbc0afb2065e0d7ec125641e0031 f38c?O penDocument.

84. I thank Geoff Corn for noting this treaty as a landmark for this vital principlc.

85. Scott, supra note 1, at xv; see also WILldAM I. HULL, THE TWO HAGUE CONFERISNCES AND THEIR CONTRIBUTIONS TO INTERNATIONAL LAW 213 (1908).

86. Scott, supra note 1, at xviii-xix. Martens acknowledged both the Brussels Declaration of 1874 and the Lieber Code in his opening remarks as President of the Subcommission charged with codification of the laws and customs of war. EYFFINGIR, supra note 47, at 269.

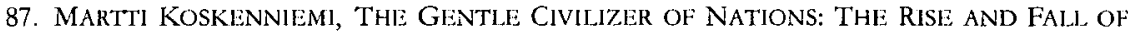
INTERNATIONAL LAW 1870-196041 (2001). The story of the development of this organization and the influence of its founders and later members is brilliantly told by Koskenniemi. 
foundation of sorts for the Hague Conference (which was called by Alexander's grandson, Czar Nicholas II).

The 1899 Hague Conference meant to build on these piecemeal past efforts. The conference was held at the House in the Woods near The Hague. ${ }^{88}$ The Convention in which the Martens Clause made its first appearance sought to regulate the conduct of occupying powers and codify the rights and duties of belligerents and civilians. In addition to the codification of the laws of war, the Conference sought to establish processes for factual inquiry, mediation, and arbitration of international disputes; adapt the 1864 Geneva Convention to maritime warfare; and proscribe or regulate the use of certain armaments. ${ }^{89}$ The work of the Convention was organized into three commissions, which were themselves compartmentalized into various types of working groups..$^{90}$ Martens was President of the Second Commission and chaired its Second Subcommission, which was tasked "to revise the Declaration concerning the laws and customs of war elaborated in 1874 by the Conference of Brussels, which has remained unratified to the present day." 11

The Conference was not called to end any particular war-in-progress or rein in any fast-massing army.92 But past wars loomed in the background. Looming largest was the Franco-Prussian War (a.k.a. The War of 1870) that destroyed the Second French Empire and unified Germany. ${ }^{93}$ In that

88. HULI, supra note 85 , at 7.

89. Scott, supra note 1 , at xvi-xix; HUL.L, supra note 85 , at $28-31,45-47$.

90. Hull, supra note 85, at 28-31; see also JAMES Brown SCOTT, THE Hagule Place CONFERIENCIES OF 1899 AND 1907, VOL. 1, at 51-54 (1909) [hereinafter Scott (1909)].

91. EYFFINGER, supra note 47, at 263.

92. Frits Kalshoven, Introduction to THE CENTENiNIAl. OF THE FIRST INTERNATIONAL PEACE CONFERENCE: REPORTS \& CONCLUSIONS 1 (Frits Kalshoven ed., 2000); see also Rescript of the Russian Emperor, Aug. 24, 1898 (Aug. 12, 1898 O.S.), reprinted in Scott, supra note 1, at 1 ("the Imperial Government thinks that the present moment would be very favorable for seeking, by means of international discussion, the most effectual means of insuring to all peoples the benefits of a real and durable peace, and above all, of putting an end to the progressive development of the present armaments."); Russian Circular, January 11, 1899 (Dec. 30, 1898 O.S.), in id. at 3-5 (expanding on subjects for consideration at the Conference, particularly "7. To revise the Declaration concerning the laws and customs of war elaborated in 1874 by the Conference of Brussels, which has remained unratified to the present day.'). For an analysis of the cynical responses to the Rescript and Circular at the time, see EYFFINGLR, supra note 47, at 16-40. For a current appraisal of ulterior Russian motives, see Eyffinger, supra note 13, at 23 ("Modern research has long verified the move for a Peace Conference as a clever bid for a military moratorium, thus to better implement Russia's ambitious schemes for upgrading the huge Empire's dramatic infrastructure.').

93. This war had also influenced the failed 1874 Brussels meeting, in which Martens had played a significant preparatory role, and made a considerable impression on Martens himself:

During the War of $1870-71$, being close to the theatre of war, I collected from the newspapers of all countries and through personal contacts all the facts which established a violation of the laws and customs of war. Already I had come to the conclusion that the establishment by the governments themselves of these laws and customs was entirely 
roughly nine-month conflict, the larger Prussian army dominated northern France and ultimately laid siege to Paris itself. A significant thorn in the side of this organized, uniformed, traditional fighting force was the socalled francs-tireurs. These fighters were not members of any state's military. Rather, they were loosely organized but unofficial groups of private riflemen. They attacked uniformed troops in sniper fashion and harassed the movements of enemy combatants by exploding bridges and railways. ${ }^{94}$ Although some wore uniforms and were authorized by the French state, "others fought entirely on their own initiative and for the most part were distinguishable from the French peasants only by a badge which was invisible at a distance and easily removable." 95 The Prussian troops harassed by these fighters spared little effort to distinguish one type from the other; one historical source declared that "[i]n the knapsack of each Franc-tireur was found a complete suit of plain clothes." "Unless an enemy fighter both wore a uniform with permanent insignia "recognizable at gunshot distance" and "carried papers showing that they formed part of the French army," their treatment upon capture would be harsh, ranging from a decade in prison to death. ${ }^{97}$

What rights did the inhabitants of occupied territory retain, and which would they sacrifice if they resisted their foreign masters? Were francs-tireurs deserving of some form of combatant immunity for their efforts to defend their country or were they not organized and regularized enough to qualify as combatants at all? In many ways, those francs-tireurs, who in James Molony Spaight's resonant phrase, "claim now the privileges of combatants now those of the peaceful inhabitants," 98 might be compared to civilians directly participating in hostilities today (which remains very much a continuing controversy). ${ }^{99}$ To varying degrees, the Additional

necessary in order to prevent endless accusations and merciless reprisals. In $1873 \mathrm{I}$ had the honour to submit this idea to my noted superior, Chancellor Prince Gorchakov. General Count Miliutin, at the time War Minister and one of the most outstanding Russian public figures, not only reacted sympathetically to this matter but hastened to extend his influential support for it. The initial draft convention on the laws and customs of warfare, prepared by myself, was subjected to detailed and attentive discussion in a commission of eminent Russian military officers under the chairmanship of General Miliutin himself.

Pustogarov, Our MARTEns, supra note 10, at 109. Martens was a member of the Russian delegation. Id. at 108. It should be noted that Pustogarov gives a confusing citation for the source of this quote, noting one in the body of the text and a different one in a corresponding footnote.

94. David Turns, Classification, Administration, and Treatment of Battlefield Detainees, in COUNTERTERRORISM: INTERNATIONAL LAW AND PRACTICE 438 (Ana Maria Salinas de Frias et al., eds. 2012).

95. JAMES MOLONY SPAIGHT, WAR RIGHTS ON LAND 42 (1911); see also Watkin, supra note 26, at 20-21.

96. SPAIGHT, supra note 95 , at 43.

97. Id.

98. Id.

99. Dr. Nils Meltzer, International Committee of the Red Cross, Interpretive Guidance on the Notion 
Protocols to the Geneva Convention provide that such civilians lose their protection from being made the lawful objects of attack during and for such time as they directly participate in hostilities but retain certain fundamental guarantees concerning their treatment upon falling into the power of the adverse party. ${ }^{100}$ The questions raised about the status of the franc-tireur then were essentially the same as those raised by concerns for today's "revolving door" civilian fighter, or what the United States now calls "unprivileged belligerents." 101 Compare, for example, the concern expressed above by Spaight in 1911 with that of Yoram Dinstein today: "a person is not allowed to wear simultaneously two caps: the hat of a civilian and the helmet of a soldier."102

The delegates in the Second Commission (of which Martens was President) were able to agree that "[t]he laws, rights, and duties of war apply not only to armies, but also to militia and volunteer corps," at least to the extent that those groups fulfilled criteria that sufficiently distinguished their members from ordinary civilians. ${ }^{103}$ To qualify, the

of Direct Participation in Hostilities under International Humanitarian Law, 90 INT'L REV. RED CROSS 991 (2008).

100. See Protocol Additional to the Geneva Conventions of 12 August 1949, and Relating to the Protection of Victims of International Armed Conflicts (Protocol I) art. 45, 51, 75, June 8, 1977, 1125 U.N.T.S. 3 [hereinafter Protocol I].

101. This term, like its predecessor, "unlawful enemy combatant", remains somewhat controversial. The terms seem intended to connote those who are deemed not to enjoy the combatant's privilege to kill or destroy free from civilian criminal sanction and yet are not fully accorded the status of civilians. Although these terms have been defined in U.S. domestic law, in the Military Commissions Act of 2006 and its 2009 amendments, respectively, see Military Commissions Act of 2006, Pub. L. No. 109-366, $₫ 3(\mathrm{a})(1), 120$ Stat. 2601 (2006), and National Defense Authorization Act for Fiscal Year 2010, Pub. L. No. 111-84, $\$ 1802,123$ Stat. 2575 (codified at 10 U.S.C. $\$ 948 \mathrm{a}(7)$ (2009)), even the U.S. Army Judge Advocate General's Legal Center and School teaches its students-future JAG officers-that these terms "are not widely recognized outside the U.S. as relevant to determining who qualifies for civilian status under the LOAC." INT'L \& OpERATIONAL LAW DEP'T, U.S. ARMY JUDGE ADVOCATE GENERAL'S LEGAL CTR. \& SCH., LAW OF ARMED CONFLICT DESKBOOK 98 (2013) available at https://www.loc.gov/rr/frd/Military_Law/pdf/LOAC-Deskbook-2013.pdf.

102. YORAM DINSTEIN, THE CONDUCT OF HOSTILITIES UNDER THE LAW OF INTERNATIONAL. ARMED CONFLICT 35 (2d ed. 2010). For Dinstein, " $\mathrm{t}$ ] he wearing of civilian clothes lies at the core of the problem." Id. at 39 n.216. The ICRC takes a broader view of the possibility of reclaiming civilian status. Compare id. at 147 ("The present writer and others belicve that a person directly participating in hostilities loses his civilian status and effectively becomes a combatant (and, for that matter, an unlawful combatant under customary international law.)" (footnotes omitted) (citations omitted)), with ICRC, supra note 99, at 1015 ("Where civilians engage in hostile acts on a persistently recurrent basis, it may be tempting to regard not only each hostile act as direct participation in hostilities, but even their continued intent to carry out unspecified hostile acts in the future. However, any extension of the concept of direct participation in hostilities beyond specific acts would blur the distinction made in IHL between temporary, activity-based loss of protection (due to direct participation in hostilities), and continuous, status- or function-based loss of protection (due to combatant status or continuous combat function)."'(internal citations omitted)).

103. Regulations Respecting the Lavs and Customs of War on Land, Annex to the Convention writh Respect to the Laws and Customs of War on Land, art. 1, in Scott, supra note 1, at 51. 
group must have a responsible command hierarchy, and its members must wear "a fixed distinctive emblem recognizable at a distance;" "carry arms openly;" and "conduct their operations in accordance with the laws and customs of war." 104 This was an expansion of the protections of combatant immunity beyond traditional armies, which the delegates expanded even further to include civilians participating in a levée en masse, that is, a "population of a territory which has not been occupied who, on the enemy's approach, spontaneously take up arms to resist the invading troops without having time to organize themselves" in such a way as to fulfill the above criteria. 105

This extension did not satisfy everyone, for it did not go far enough. It still left out a variety of types of resistance fighters. To note only one example mentioned above, the guerrilla tactics of some francs-tireurs, who fought and then dissolved back into the population, were successful precisely because they did not comply with the agreed criteria for extending the status of belligerents to them. For smaller states like Belgium, the patriotism that led such fighters to rise up was not a source of defense its delegates wished to discourage or outlaw. ${ }^{106}$ On the other hand, the larger states like Germany and Russia saw no benefit to them (and considerable harm to civilian populations they sought to pacify as occupiers) in extending rights without duties to the franc-tireur. ${ }^{107}$ Consider how the remarks of a German delegate resonate with concerns today about the insurgent who, with neither uniform nor command control by any organized state power, attacks a state's armed forces and then melts back into the civilian population:

Is it so difficult, moreover, to hoist some distinctive sign? A mere arm badge will suffice. Is it too much to demand that they bear arms openly and that they observe the laws of war, a thing which they expect and of which they are assured on the part of their adversaries? ... And since we are speaking of humanity, it is time

\footnotetext{
104. Id. at art. $1,1-4$.
}

105. Id. at art. 2 .

106. Consider, e.g., the stirring remarks of General Künzli of Switzerland, in praise of the people of another small country, the one hosting the conference: "And if you will allow me to cite an example to you, I will ask you whether the most glorious epoch of the country in which we are enjoying such generous hospitality was not the one in which it had to sustain a long and arduous struggle against a powerful invader, when the whole Dutch people fought with a valiance and perseverance without parallel for its independence, freedom and convictions? ... [D]o not punish love of country; do not adopt rigorous measures against peoples who rise in a mass to defend their soil." EYFFINGER, supra note 47 , at 304.

107. Rotem Giladi, The Enactment of Irony: Reflections on the Origins of the Martens Clause, 25 EUR. J. INT'L L. 847, 850 (2014) ("Broadly speaking, this was a debate between small and great powers. The former, led by Belgium, had some support from Great Britain; the latter consisted of Russia and Germany."). 
to remember that soldiers are also men, and have a right to be treated with humanity. Soldiers who, exhausted by fatigue after a long march or a battle, come to rest in a village have a right to be sure that the peaceful inhabitants shall not change suddenly into furious enemies. 108

Thus, the problem of francs-tireurs threatened the Conference. The Great Powers of Europe saw these fighters as deserving of harsh punishment, not the rights of belligerents. ${ }^{109}$ Their conduct was not to be condoned by granting any legal status or protections under the law. Other states (mostly smaller countries who feared the speed with which they could be-and frequently were-overrun by larger armies) wanted the franc-tireurs to fall under the protection of the law of war notwithstanding their guerilla tactics and loose organization as insurgents. 110 Martens recognized the difficulty of squaring this circle: "We wish to save the life and property of the weak, the unarmed, and the inoffensive, but we by no means wish either to prescribe laws for heroes or to curb the impulse of patriots."111 There were, of course, many other conflicts between small and great powers concerning drafts proposed at the Conference, but this one was perceived to be a threat to the entire enterprise. ${ }^{112}$

The Martens Clause that emerged was the successful compromise that saved the conference. One of the Belgian diplomats who led the opposition, Édouard Descamps, couched his delegation's objections in terms of "the cause of humanity," "the demands of civilization," and "the lessening of the evils of war." 113 Martens may have seized upon these

108. EYFFINGLR, supra note 47, at 305 (quoting the German delegate Colonel Gross von Schwarzhoff); see also THE REPORTS TO THI HAGUE CONPERIENCES OF 1899 AND 1907 141-142 (James Brown Scott ed., 1917) [hereinafter Scott (1917)] (referencing similar remarks by Col. Gross von Schwarzhoff, as summarized by the reporter Mr. Rodin).

109. SPAIGHT, supra note 95, at 41-45. Spaight quotes Martens in this section both for a description of the severe punishments meted out to francs-tireurs by their German captors and to punished civilian populations decmed collaborators by advancing German armies, id. at 41 , n.4, and for the conclusion that public opinion in "the neutral states of Europe" held this treatment to be "too cruel." Id. at 45 n.2.

110. V.V. Pustogarov, The Martens Clause in International Lan, 1 J. HISTORY OF INT'L L. 125, 126 (1999).

111. EYFFINGER, supra note 47 , at 305.

112. Pustogarov, supra note 110 , at 126; Jochen von Bernstorff, Martens Clause, in MAX PLANCK ENCYCLOPEDIA OF PUBLIC INTERNATIONAL. LAW (2009), available at http://opilouplaw.com/vicw/10.1093/law:epil/9780199231690/law-9780199231690c327? rskey=Zsx3hG\&result=1\&prd=EPIL.

113. Pustogarov, supra note 110, at 126; PUSTOGAROV, OUR MARTiNS, supra note 10, at 176. There appears to be disagreement in the sources whether Descamps or his superior colleague, $M$. Becrnaert, spoke in opposition. See HuLL, supra note 85, at 215-20 (citing Beernaert's contributions, but not Descamps, in debate orer belligerent status); id. at 243-56 (citing both Becrnaert and Descamps regarding debate over the occupation of hostile territory); see also Edouard Rolin, Report to 
words in formulating the preambular clause that bears his name and saved the Conference. ${ }^{114}$ The Clause, translated into English from the original French, states the following:

Until a more complete code of the laws of war is issued, the High Contracting Parties think it right to declare that in cases not included in the Regulations adopted by them, populations and belligerents remain under the protection and empire of the principles of international law, as they result from the usages established between civilized nations, from the laws of humanity, and the requirements of the public conscience. ${ }^{115}$

Summarizing Martens's arguments, Antonio Cassese noted an aspect of particular relevance to the propensity of the Bush Administration to exploit perceived gaps in the law of armed conflict. According to Cassese, Martens argued the following:

[T] fail to agree upon specific treaty rules would have the consequence of showing to the military that for the second time (the first being the Brussels Conference of 1874) experts and diplomats could not fashion rules on the matter. Consequently, the military would feel free to interpret the laws of warfare as they pleased. ${ }^{116}$

The core of the Clause, which first appeared in the Preamble to the Hague Convention, reappears in Article 1 of Additional Protocol I to the

the Conference from the Second Commission on the Laws and Customs of War on Land, in Scott (1917), supra note 108, at 139-41 (citing Beernacrt's remarks); EYFFINGER, supra note 47, at 271 (citing only the remarks of Beernaert). But see id. at 303 (citing remarks of Descamps on belligerent status). This may be attributable to the fact that " $[t]$ here was not a single stenographer among its secretaries, and the minutes of each meeting were not verbatim reports, nor were any copies of them, nor any documents connected with the proceedings, permitted to be published." HULL, supra note 85, at 22. Research in this area is further complicated by the fact that, although French was the official language of the Conference and the ordinary (although not exclusive) language of communication, see Scott (1909), supra note 90 , at 53, most English-language texts omit reference to any source for translations of reported speech.

114. Pustogarov, supra note 110 , at 127 ("Being well acquainted with Descamps through the Ghent Institute of International Law, Martens asked to be given the instruction received by Descamps. He sat on it until late at night, and in the morning of the following day, he presented his proposal to the commission.").

115. Scott, supra note 1, at 48. The French text is: 'En attendant qu'un code plus complet des lois de la guerre puisse être édicté, les Hautes Parties contractantes jugent opportune de constater que, dans les cas non compris dans les dispositions réglementaires adoptees par Elles, les populations et les belligérants restent sous la sauveguarde et sous l'empire des principes du droit des gens, tells qu'ils resultant des usages établis entre nations civilisées, des lois de l'humanité et des exigencies de la conscience publique."

116. Antonio Cassese, The Martens Clause: Half a Loaf or Simply Pie in the Sky?, 11 EUR. J. INT'L L. $187,195(2000)$. 
Geneva Conventions, the 1977 treaty that supplements the scope of application of the Geneva Conventions in international ("Common Article 2") conflicts. ${ }^{117} \mathrm{~A}$ more abbreviated form appears in the Preamble to Additional Protocol II, which develops and supplements the Geneva Conventions in non-international ("Common Article 3") conflicts that meet a certain material threshold.118 (As will be noted below, this manner of truncation is significant.) It also appears in the concluding paragraphs of each of the articles covering denunciation of the four Geneva Conventions. ${ }^{119}$ Thus, a connection is established to the Martens Clause for armed conflicts to which neither additional protocol applies. (The Geneva Conventions do not contain preambles, which led the drafters to conclude that the Martens Clause was most appropriately included in their respective articles of denunciation, "in order to underline in a succint [sic] fashion that even denunciation could not result in a legal void.") 120 Of course, if no "armed conflict" is deemed to exist, then the Martens Clause, the Additional Protocols, the Geneva Conventions, the customary international law of armed conflict-none of these apply.

Concededly, there is not just one interpretation of the Martens Clause. Many scholars have analyzed the merits of broad and narrow interpretations of the Martens Clause. ${ }^{121}$ Some have viewed the Clause as a

117. Protocol I, supra note 100 ("In cases not covered by this Protocol or by other international agreements, civilians and combatants remain under the protection and authority of the principles of international law derived from established custom, from the principles of humanity and from the dictates of public conscience.").

118. Protocol Additional to the Geneva Conventions of 12 August 1949, and Relating to the Protection of Victims of Non-International Armed Conflicts (Protocol II) preamble, June 8, 1977, 1125 U.N.T.S. 609, 611 [hereinafter Protocol II] ("Recalling that, in cases not covered by the law in force, the human person remains under the protection of the principles of humanity and the dictates of the public conscience"). Additional Protocol II applies to non-international armed conflicts not covered by Additional Protocol I that involve non-state armed groups "which, under responsible command, exercise such control over a part of [the State Party's] territory as to enable them to carry out sustained and concerted military operations and to implement this Protocol" and that are not "isolated and sporadic acts of violence" that do not rise to the level of armed conflicts. $I d$.

119. See Geneva I-IV, supra note 30, arts. 63, 62, 142, and 158, respectively ("FDenunciation] shall in no way impair the obligations which the Parties to the conflict shall remain bound to fulfill by virtue of the principles of the law of nations, as they result from the usages established among civilized peoples, from the laws of humanity and the dictates of the public conscience."); see also Theodor Meron, The Martens Clause, Principles of Humanity, and Dictates of Public Conscience, 94 AM. J. INT'L L. 78,78 n.3 (2000).

120. Zimmermann, supra note 11 , at 38 (53).

121. See, e.g., Giladi supra note 107 , at 853 "Martens' response temains a classic example of power politics veiled by humanitarian rhetoric; it also cunningly harped on the political and professional sensitivities besetting his audience."); see also Cassese, supra note 116, at 187-216; Pustogarov, supra note 110, at 125-35; Emily Crawford, The Modern Relevance of the Martens Clause, in ISIL YEARBOOK OF INTERNATIONAL HUMANITARIAN AND REFUGEE LAW, VOL. 6, at 1-18 (2006); Rupert Ticehurst, The Martens Clause and the Laws of Armed Conflict, 37 INT'L REV. RED Cross 125-34 (1997); von Bernstorff, supra note 112; and, of course, Pictet's commentaries to the Geneva Conventions and 
signifier of background principles of customary international law that the ratification of treaties may not be seen to erase. ${ }^{122}$ Still others would point to the reference to "public conscience" as an additional, determinable source of public international law that constrains state action beyond treaties, perhaps as a source of customary international law or perhaps even as a free-standing constraint. ${ }^{123}$ Recent and thorough consideration of its application may be found in the various written submissions to, and (primarily dissenting) opinions by, the International Court of Justice in 1996 in its advisory opinion on nuclear weapons.124 As Rupert Ticehurst notes, "[t]he positions advocated by States in their submissions to the ICJ on the issue of nuclear weapons and the differing opinions the judges gave in response reflect the continuing divide in international law between positive and natural law.'"125

\section{IV. “PROTECTION \& EMPIRE”: INDIVIDUAL RIGHTS AND SOVEREIGNTY}

It is not necessary to join this dispute about application and content in order to note the role the Martens Clause played in salvaging the first Hague Peace Conference. Its importance is underscored by its recurrence in subsequent international treaties and judicial opinions. And, as the International Court of Justice noted, it "has proved to be an effective

their additional protocols.

122. Mary Ellen O'Connell, Development and Legal Basis, in THE HANDBOOK OF INTERNATIONAI. Humanitarian LaW 31 (Dieter Fleck ed., $2 d$ ed. 2008). See also Prosecutor v. Kupreskic, Case No. IT-95-16-T, Judgement, 97 525, 527 (Int'l Crim. Trib. for the Former Yugoslavia Jan. 14 2000) ("True, this Clause may not be taken to mean that the 'principles of humanity' and the 'dictates of public conscience' have been elevated to the rank of independent sources of international law, for this conclusion is belied by international practice. However, this Clause enjoins, as a minimum, reference to those principles and dictates any time a rule of international humanitarian law is not sufficiently rigorous or precise: in those instances the scope and purport of the rule must be defined with reference to those principles and dictates... This is however an area where opinio iuris sive necessitatis may play a much greater role than usus, as a result of the aforementioned Martens Clause. In the light of the way States and courts have implemented it, this Clause clearly shows that principles of international humanitarian law may emerge through a customary process under the pressure of the demands of humanity or the dictates of public conscience, even where State practice is scant or inconsistent. The other element, in the form of opinio necessitatis, crystallising as a result of the imperatives of humanity or public conscience, may turn out to be the decisive element heralding the emergence of a general rule or principle of humanitarian law.').

123. Legality of the Threat or Use of Nuclear Weapons, Advisory Opinion, supra note 17, 40611 (Shahabuddeen, J., dissenting).

124. These positions are nicely summarized by Ticehurst, supra note 121 , at $126-28$. The Advisory Opinion itself (as opposed to the opinions submitted by its individual members) gave less treatment to the Martens Clause. Nevertheless, it does appear that the Court concluded that the Martens Clause is a norm of customary international law "whose continuing existence and applicability is not to be doubted," not merely an aspirational statement. $S_{e e}$ Legality of the Threat or Use of Nuclear Weapons, $A$ dvisory Opinion, supra note 17 , at q| $84,87$.

125. Ticehurst, supra note 121, at 131. Accord Cassese, supra note 116, at 210. 
means of addressing the rapid evolution of military technology," not to mention a constant reminder of the evolving nature of armed struggles more generally. ${ }^{126}$ These are all indicia that the Clause continues to capture an international consensus that states should no longer feel any freedom to return to an international environment in which they may exploit the non liquet to obtain strategic or tactical benefit against other states or non-state adversaries.

This itself is a substantial change in public international law. It is one that the legal position of the Bush Administration does not appear to have recognized. That administration's view of the Geneva Conventions was a classic a contrario argument: since the armed struggle against international terrorism naturally supposed a response based on the law of armed conflict, but did not fit within the textual confines of Common Articles 2 or 3 (being neither "international armed conflicts" nor "armed conflicts not of an international nature"), the Bush Administration argued that its actions were not governed by any law of armed conflict. ${ }^{127}$ At the same time, the Bush Administration claimed authority to apply "the law of war to a conflict to which the Convention does not apply." 128 Of all the sources to cite for support for this contention, the Administration cited Article 142 of the III Geneva Conventions, which contains the reconstituted Martens Clause! ${ }^{129}$ As Marko Milanovic observed: "It must be noted that it certainly takes some audacity to cite the Martens Clause, of all things, which embodies the humanitarian spirit of the laws of armed conflict, as support for the thesis that there are armed conflicts which are governed by the law of war but are not regulated by it, and all for the purpose of torturing suspected terrorists for information."130

The Martens Clause rejects this a contrario argument because it rejects two fundamental foundations for this interpretation of humanitarian I 78.

126. See Legality of the Threat or Use of Nuclear Weapons, Advisory Opinion, supra note 17, at

127. See, e.g., Memorandum from George W. Bush to Vice President, et al. supra note 23, at 93. For an early and prescient counter-argument, and perhaps the first to use the term "transnational armed conflict," see Gcoffrey S. Corn, "Snipers in the Minaret-What is the Rule?" The I.al" of War and the Protection of Cultural Property: A Complex Equation, ARMY LAW, 28, 31 n.27 (Jul. 2005).

128. Brief for Respondents, Hamdan v. Rumsfeld, supra note 24, at 26.

129. Id. at 26 n.5.

130. Marko Milanovic, Lessons for Human Rights and Humanitarian I an in the War on Terror: Comparing Hamdan and the Israeli Targeted Killings Case, 89 INT'L. REV. RED CROSS 373, 377 (2007) ("Here we have the first example of the Martens Clause being cited by a government for purposes which are everything but humanitarian."); see also Hans-Joachim Heintze, Terrorism and Asymmetric Conflicts A Role for the Martens Clause?, in A WISER CENTURY? JUDICIAL DISPUTE SETTIJEMENT, DisARMAMENT AND THE LAWS OF WAR 100 YEARS AFTER THE SECOND HaGUL PEACE CONFERENCE 429, 432-33 (Thomas Giegerich ed., 2009) (criticizing this "quite unique" and "strange interpretation" of Article 142 for its historical, logical, and humanitarian inconsistencies). 
protections: first, the return to a world in which public international law is composed of nothing more than accretions of sovereign will; and second, an interpretation of international law that permits a state to invoke the authority of armed conflict while simultaneously disavowing any humanitarian obligations related to the victims of that armed conflict.131 Even as strong a critic of a broad reading of the Clause as the respected international jurist Antonio Cassese was willing to accept "a further reason for attaching some legal value to the clause: namely, the general principle of construction whereby international instruments should not be presumed to be devoid of any legal significance and practical scope."132 Thanks to the Martens Clause, "if cases are not covered by the rules of the Hague or Geneva Conventions, it does not necessarily follow that they are unregulated, for they may be governed by customary rules-if such rules exist with regard to a particular matter-or other treaties." 133 Ironically enough, this was the very position the United States advanced in its submissions to the International Court of Justice in the Nuclear Weapons Case. ${ }^{134}$

There is another hint to the continued vitality of the Martens Clause (although it is only a hint) to be found in the different formulations of the clause in Additional Protocols I and II to the Geneva Conventions. Although it is only a hint, a close examination of word choice in the restyling of the Martens Clause in these two protocols suggests a shift from the old view that international law had no application in contexts purely internal to a sovereign state.

Additional Protocol I (AP I) concerns armed conflicts "in which peoples are fighting against colonial domination and alien occupation and against racist régimes in the exercise of their right of selfdetermination...."135 In that context, the Martens Clause, restyled in Article 1(2), assures civilians and combatants that they "remain under the protection and authority of the principles of international law derived

131. Zimmermann, supra note 11 , at 1341 ("If a case is 'not covered by the law in force', whether this is because of a gap in the law or because the parties do not consider themselves to be bound by common Article 3, or are not bound by Protocol II, this does not mean that anything is permitted. 'The human person remains under the protection of the principles of humanity and the dictates of the public conscience': this clarification prevents an a contrario interpretation. Since they reflect public conscience, the principles of humanity actually constitute a universal reference point and apply independently of the Protocol.").

132. Cassese, supra note 116 , at 212 .

133. Id. at 211 .

134. Id. Cassese quotes the U.S. representative before the ICJ: "[The Clause] makes clear the important protective role of the law of nations and clarifies that customary international law may independently govern cases not explicitly addressed by the Conventions. This is what gives content and mcaning to the Martens Clause." Id at $211 \mathrm{n} .70$.

135. Protocol 1, supra note 100 , art. 1. 
from established custom, from the principles of humanity, and from the dictates of public conscience." Relatively little is changed from the original: the reference to "civilized nations" is replaced with "custom" and "authority" is substituted for "empire."

Additional Protocol II (AP II) adds to existing protections afforded by Common Article 3 only in cases (1) that are not covered by Article 1 of AP I and (2) that "take place in the territory of a High Contracting Party between its armed forces and dissident armed forces or other organized armed groups which, under responsible command, exercise such control over a part of its territory as to enable them to carry out sustained and concerted military operations and to implement this Protocol." 136 The Martens Clause restyled in its preamble makes no mention of "authority" and no mention of "the principles of international law derived from established custom." Why? The Commentary indicates only that this shorter wording "takes into account the specific nature of noninternational armed conflicts." 137

What role does international law play when there is "protection" without "authority," or, to use the original language of the Martens Clause, "protection" without "empire"? The answer is suggested by this textual distinction between AP I and AP II. AP I expressed the greater willingness of the world community of states to broaden protections for fighters organized against "colonial domination and alien occupation and against racist regimes in the exercise of their right of self-determination." 138 Those particular prior claims to sovereignty were more subject to criticism than they had been in the past. And those who fought against colonial powers were correspondingly less objectionable, or at least pragmatically deemed to be potential future members of the community of sovereign states, than in the past. If AP II "shall apply to all armed conflicts which are not covered" by AP I, that is the universe of conflicts in which those more acceptable contestations of claims to sovereignty are absent. No claim of sovereignty (other than that of the only sovereign party to the conflict) could be raised as a shield covering all of the fighters and civilians affected by the conflict.

136. Protocol 11, supra note 118 , art. 1

137. Zimmermann, supra note 11 , at 4433 . The Commentary also suggests that the omission of a reference to custom perhaps reflects an overly cautious view of state practice as insufficiently developed-i.e., a bow to novelty. The Commentary states that "[i]n our opinion this cautious point of vicw requires some clarification as there is more to it than that." Rather than fixate on the newness of categorizing conflicts as internal or international, the Commentary notes that the substance of practice may be considered to date back to the Lieber Code. Id. at श 4435.

138. Protocol I, supra note 100 , art. 1. 
That left only "protection," not "authority" (or "empire”). But protection alone is enough in the late twentieth century because the protection of internationally recognized individual rights exists today without the need or requirement of support in the empire of sovereignty. Individuals are, in respects relevant for the goals of the Martens Clause, subjects of international law. States no longer have the sovereign power to opt out of respect for them just as a state's assertion of support for them, while certainly agreeable, is not necessary to their existence. What remains are the obligations of all parties - state and non-state actors-that stem not from authority/empire/sovereignty, but singularly from the protection to which all individuals are held to be entitled under international law.

Consideration of emerging state practice demonstrates the conceptual change in the relationship between individual rights and sovereignty. Martens and his contemporaries believed in the absolute sovereignty of states, a concept with no room for the claim that states were obligated to protect certain individual rights. That is quite a different world than our own, in which a position at the opposite extreme is sometimes heard: precipitous claims of one state's responsibility to protect the inhabitants of a different state from repression by that state's government.

\section{A. Individual Rights and Sovereignty in Martens's Day}

Why "protection without empire" should be the case in our own day, but not in Marten's, may be explained by a thought experiment. When Martens wrote his famous clause, he was representing a Russian state besieged by transnational terrorists. Martens's participation in the 1899 Hague Peace Conferences coincided with increasing terroristic violence claiming the lives of Russian ministers and civilians, not to mention the uptick in similar anarchist violence in Europe and America. The Russian response was as repressive as the Empire could muster. The Czar granted no quarter to his transnational enemies and did not hesitate to use military courts and summary executions to combat them. Did Martens think the Martens Clause should constrain the will of the Czar?

Absolutely not. Martens had no interest in bringing the Russian government's aggressive response to terrorism under public international legal principles. Russia was free to use its military within the broad confines of its empire unrestricted by any duties to conform that use to any positive or customary international law.

Why wasn't the Martens Clause equally applicable both abroad and at home? Martens might well have met such a suggestion with a look of bare incredulity. His non-comprehension would be similar to that of Thomas Jefferson writing about the uncivilized cruelty of British treatment of American prisoners of war in the same letters in which he boasts of the 
scorched earth annihilation of entire settlements of American Indians. 139 To Martens and even the more liberal international lawyers of his era (as with Jefferson before them), the legal regulation of military conflict was limited to wars between civilized states. ${ }^{140}$ There was, of course, racism present in the way some privileged (mainly European) civilization over the barbarism perceived in others. But the crucial distinction that mattered at least as much as the matter of civilization was the matter of sovereignty: the war to be regulated must be between states. State action directed at another state or its citizens might be subject to negotiation between (again, civilized, mostly European) states. But within its own perceived borders, the state knew no equal. There was no protection for a sovereign state's nationals against force, even military force, directed inward. Within a state's own borders, no law applied save that of the state itself.

Martens's theories of international law were complex but unbending. On the one hand, he appeared to hold to the view, anomalous for his time, that individuals were "subjects of rights in the domain of international relations." 141 In this philosophy of the source of international community may be found Martens's belief in the power of international law to establish a meaningful codification of the jus in bello: civilians and belligerents, as human beings, were entitled to certain tights and obliged to certain duties. On the other hand, this willingness of civilized states to bind themselves by international treaties in no way legitimated, in his view, any restriction of their own sovereignty, particularly the right to complete dominion over their own territories; interference by one state in the internal affairs of another state was "always illegal."142

139. JOHN FABIAN WITT, LINCOIN'S CODE: THE: LAWS OF WAR IN AMIERICAN HISTORY 35 (2012).

140. One such lawyer, an English barrister named John Westlake (who was involved in the publication of the first international law journal, the Revue de droit international et de legislation compare), "did not find it difficult to imagine that a colonizer might need to take 'punitive expeditions' in cases of 'inroads or other outrages committed by savages of half civilised tribes." KOSKENNIEMI, supra note 87 , at 86 .

141. PUSTOGAROV, OUR MARTENS, supra note 10, at 76-77 ("All contemporary civilized (sic) States are agreed that man is a person, that is, a subject of certain inalienable rights which must be respected in the domain of their mutual relations. Therefore every person, irrespective of citizenship or nationality, presently finds protection of his person and ownership throughout the entire space of the operation of international law. The ultimate purpose of the State and the purpose of international relations is the protection of the person.").

142. Id. at 67. Eyffinger points to an important caveat to Martens's commitment to the inviolability of sovereign borders: "[T] he State's autonomy and territoriality he deemed sacrosanct and military intervention he held for unacceptable, within the brotherhood of 'civilised nations' that is: the interference with the domestic affairs of barbaric realms, for instance with a vicw to forestalling the persecution of Christians, he deemed perfectly legitimate." Eyffinger, The Fourth Friedricb Martens Menorial Lecture, supra note 13, at 21. 
When it came to applying these principles to issues that mattered to him, Martens tended to the conventional view of the state's absolute sovereignty. Thus, Martens opposed the Russian Empire's refusal to recognize any right of expatriation for Russian subjects (a policy contrary to the practices of many states at that time). ${ }^{143}$ But Martens supported the Russian policy, another distinctly minority position, of insisting upon the extradition to Russia of subjects (since they remained Russian subjects) accused of political crimes. 144 Why, Martens asked, should political asylum be granted to those "who call themselves socialists, anarchists, and 'dynamiters' and who have declared war to the death against any Government?"'145

As Martti Koskenniemi notes, Martens argued the same point at the Institut de Droit international, "in a somewhat circular way," that such people were not "real" political refugees, but mere criminals possessed of the "instincts bestiaux de l'homme." 146 The leadership of the Institut agreed with Martens in at least one respect, again summarized by Koskenniemi: "anarchism and communism were crimes against all States, to be combated by all available means." 147 (Here it should be noted that "European popular opinion, and also many individual members of Western official circles, tended to regard the Russian comrades as freedom fighters, justified in principle [if misguided in tactics] in their struggle against the despotic and semibarbaric regime in their motherland.") ${ }^{148}$

Thus, in arguing for his eponymous clause and the larger work of codification of which it was a part, Martens worked within a conception of the absolute sovereignty of states. The Hague Convention could only affect the behavior of state signatories when they engaged in "war" in the sense understood by international law at that time: that is, war was an interstate-and only interstate-armed conflict. Martens asked states to establish a "mutual insurance association against the abuse of force in time of war." 149 Comparing this form of organization to that of a private insurance company, he narrowly restricted the benefits obtained to those who agreed to the terms of the policy and the by-laws of the company:

143. Lauri Mälksoo, F.F. Martens and His Time: IVben Russia Was an Integral Part of the European Tradition of International law, 25 EUR. J. INT"I. L. 811, 823 (2014) ("In the context of human rights, Martens defended unconditionally, for example, the right of individual citizens to emigrate.").

144. Pustogarov, Our MARTENS, supra note 10 , at 271-72.

145. Id. at 272 .

146. See KOSKENNIEMI, supra note 87 , at 68 .

147. Id. at 69 . Koskenniemi notes "how easily the men of 1873 could fall back on repression in order to defend their aristocratic liberalism" and situates this particular animosity within these international lawyers' "manly determination to repress the spread of socialist ideas." Id. at 69-70, 77.

148. GEIFMAN, supra note 51 , at 38 .

149. Rolin, supra note 113 , at 139. 
Now, Gentlemen, one is free to join an association or not, but in order that it may exist it must have by-laws. And in insurance companies, for instance those against fire, hail, or other calamities, the by-laws which provide for these disasters do not regulate, but recognize the existing dangers. . . . It is for the Governments to enter the society or not, to accept or reject the hand extended to them. However, only the member will benefit by all the advantages which will be offered by this society in times of war. ${ }^{150}$

These remarks were to oppose the view of General Sir John Ardagh, a British delegate, who encouraged the Commission to settle for something short of a formal treaty. The 1874 Declaration of Brussels, on which the Commission based its codifying work, had not been adopted in treaty form by states. In Ardagh's opinion, this was the preferred course: after the Commission was done improving its language "we would better accept the Declaration only as a general basis for instructions to our troops on the laws and customs of war, without any pledge to accept all the articles as voted by the majority." 151 For Martens, international law inevitably led to the conclusion that a formal treaty be adopted: "This is the only way of obtaining an obligation binding on the signatory Powers. It is well understood that the Declaration of Brussels will have no binding force except for the contracting or acceding States." 152

So there could be no question of applying his clause, let alone the rest of the Hague Convention, to terrorists. When anarchists and fighters sought refuge from (or plotted against) Russia abroad, Russia demanded their extradition. To the extent that anarchists and nihilists operated within Russia, the Empire had absolute sovereignty to choose any means by which to deal with its own subjects.

Had the concept of sovereignty not been so rigidly accepted in the relations between states, the Martens Clause may have had application in the fight against these fin-de-siècle transnational terrorists. But sovereignty remained a concept that seemed to brook no intermediate approach under international law. ${ }^{153} \mathrm{~A}$ state was either sovereign or it was not. Consider the

150. EYFFlNGER, supra note 47 , at 300 .

151. Rolin, supra note 113 , at 138 .

152. Id. at 139 (emphasis omitted).

153. Ticehurst, supra note 121, at 131 ("By the end of the nineteenth century, concepts of legal positivism and State sovereignty had become dominant in international legal thinking. . . Through a positivist interpretation of international law, States which do not consent to being bound by treaty norms or to the development of customary rules remain outside the regime governed by those norms: subjugation to a positive norm is dependent on the will of the State. It is therefore consensual law. If that will is absent, the State is not bound by that norm and so is not responsible to the international community for non-observance of it."). 
reasoning of Martens's British contemporary, James Molony Spaight, at the conclusion of his lengthy monograph on the laws of war after the Hague Convention and the first Geneva Convention of 1906:

As I have said in the first chapter of this book there is no machinery for compelling compliance with International Law. International Law will never have a real "sanction," that is, it will never be really "law" in the strict Austinian sense, unless and until the various nations surrender some of their sovereign power to one supreme ruler who shall have the right and the means to execute his decrees. Such a "High King" - a revived Pope, for instance, with a "ten-power standard" army and fleet and the right to refrain the spirit of refractory princes, not by excommunicating them, but by marching against them, smiting them hip and thigh, and imprisoning them in the Vatican - would certainly dispense a "law," but whether that law would then be International Law is doubtful. For, practically, so far as foreign affairs were concerned, the nations would not be independent and sovereign. ${ }^{154}$

Even a project such as envisioned (but never realized) under Chapter VII of the U.N. Chatter (especially the "special agreement or agreements" of Article 43) - as near to a "High King" with "'ten-power standard' army and fleet" as imaginable-would not result in real international law. Why? Because such a power above states would render states something less than absolutely sovereign over their foreign affairs.

What hope, then, for the introduction of the Martens Clause to govern armed conflicts not of an international character, an even more sacrosanct aspect of sovereignty than the conduct of a state's armies in the field? None. Indeed, the report to the Conference as a whole of the codification work done by the Second Commission on the Laws and Customs of War on Land that Martens chaired made the following perfectly clear:

$[\mathrm{N}]$ one of the articles of the draft can be considered as entailing on the part of adhering States the recognition of any right whatever in derogation of the sovereign rights of each of them, and that adhesion to the regulations will simply imply for each State the acceptance of a set of legal rules restricting the exercise of the power that it may through the fortune of war wield over foreign territory or subjects. 155

154. SPAIGHT, supra note 95 , at 461.

155. Rolin, supra note 113 , at 140 . 
But this system was in flux. Take the so-called "temporary regulations" imposed after the assassination of Czar Alexander II in 1881. These laws (which turned out to be permanent-they lasted until the fall of the Romanovs) were hated because they allowed for all sorts of summary, arbitrary, and extreme arrests, detentions, trials, and punishments. But had Russia-like most of Europe-not already begun to restrict absolutist monarchies with constitutional reforms that infringed the discretion of the sovereign, the promulgation of these Temporary Regulations would not have been necessary in the first place. They were a retreat from a general trend of restricting the sovereign's power. As Jonathan Daly observed,

Historically, absolutist governments did not adopt comprehensive emergency legislation since their 'normal' laws were already sufficiently arbitrary and severe. But as the power of European monarchs began to be limited, whether voluntarily or under duress, constitutional restraints instituted for the protection of citizens occasionally hampered states' abilities to defend themselves against forces threatening their very existence. Prudence then dictated the temporary suspension of constitutional restraints. Ironically, such suspensions were the hallmarks of transitions from absolutist to constitutional rule, from early modern Polizeistaat, or rationalized absolutism, to the rule of law. ${ }^{156}$

Sovereignty still retains its place. But it is not the same place that it once was relative to the inherent right of individuals regardless of the state's preferences for their treatment. That modern relationship is considered next below.

\section{B. Individual Rights and Sovereignty in Our Day}

Fast-forward one hundred years from the transnational terrorism that afflicted the Russian Empire. Imagine if the Martens Clause had been drafted not in 1899 but in 1999 . Though the text of the Clause would be exactly the same, how would its meaning be understood in the context of our own turn-of-the-century understanding of international law? That is a very different context from the one F.F. Martens inhabited. ${ }^{157}$ This Article

156. Jonathan W. Daly, On the Significance of Emergency Legislation in Late Imperial Russia, 54 SI_AVIC REV. 602, 603 (1995) (footnotes omitted).

157. For a suggestion that Martens might have been less surprised by the diminishing importance of sovereignty than suggested here, see Mälksoo, supra note 143, at, 822 ("For instance, Martens held - in the early 1880 s-that the system of international law was no longer built on the absolute sovereignty of states, but on the idea of an international community of which sovereign states were 
is not the place for a recitation of the creation and growth of the international law of human rights. It is sufficient to note that " $[t]$ hough it has pre-war antecedents, the movement for the international protection of human rights is largely a product of the Second World War and its immediate aftermath." 158

As we move through time from Martens's day to our own, we cease to occupy spaces in which the international law of armed conflict placed no constraints on the purely domestic actions of sovereign states. With the introduction by treaty of the law of armed conflict into conflicts "not of an international character" beginning in 1949, the Martens Clause gained entrée to domestic applications. This also opens the way for its application in armed conflicts with non-state actors in ways that Martens and his contemporaries would have had great difficulty imagining in 1899 .

Terrorists still plague Europe. The Madrid train bombings of March 11, 2004, killed 191 and injured more than 1,800.159 The London public transport bombings of July 7,2005, killed 52 and injured 770.160 These statistics don't include the attempts in London, Glasgow, and elsewhere that did not succeed (much like the failed Greenwich Observatory attempt that inspired Joseph Conrad). The ICRC takes the position that these and other terrorist attacks, taken together, do not satisfy the criteria of common organization or intensity sufficient to be categorized as an armed conflict under international humanitarian law.161

Terrorism also continues to plague Russia. Terrorists, many originating from Chechnya, have been responsible for a campaign of bombing subways, apartment buildings, and public spaces that between 1998 and 2011 averaged more than 68 casualties every 6 months. ${ }^{162}$ But again, the

merely a part."). On the other hand, Martens "did not yet enlist individuals as full subjects of international law, [although] he considered them to be part of the international community and as having specific rights protected by it." Id. at 823 (internal citations omitted).

158. A.W. BRIAN SIMPSON, HUMAN RIGHTS AND THE END OF EMPIRE: BRITAIN AND THE GENESIS OF THE EUROPEAN CONVENTION vii (2001).

159. Paul Hamilos, 21 Guilty, Seven Cleared over Madrid Train Bombings, THE GuARDIAN (Oct. 31, 2007), http://www.theguardian.com/world/2007/oct/31/spain.marktran.

160. 7 July Bombings Overview, BBC NEws (undated), http://news.bbc.co.uk/2/shared $/ \mathrm{spl} / \mathrm{hi} / \mathrm{u}$ $\mathrm{k} / 05 /$ london_blasts/what_happened/html.

161. It should be clear that this Section presents a hypothetical exercise. The ICRC has concluded that, as a factual matter, such an assumption is not borne out by the facts. ICRC 30TH CONFERENCE REPORT, supra note 28, at 725 ("In other words, can it be said that the bombings in Glasgow, London, Madrid, Bali or Casablanca can be attributed to one and the same party to an armed conflict as understood under IHL? Can it furthermore be claimed that the level of violence involved in each of those places has reached that of an armed conflict? On both counts, jt would appear not.').

162. Attacks in Moscow: 1996-2011, CBC-RADIO CANADA News. (Jan. 24, 2011), http://www.cbc.ca/news/world/attacks-in-moscow-1996-2011-1.1008425. A tabular summary of these attacks brings home the scale of the terrorist threat. One is provided in the Appendix to this Article. 
source of these attacks was not always the same, or even always known, and sometimes highly controversial. ${ }^{163}$ Nor does their intensity or frequency match the rate of terrorism at the turn of the nineteenth century. As noted above, terroristic violence averaged 18 casualties a day in 1907. Perhaps the only parallel is with the reluctance of diplomats in Martens's day to accept the restraints of the law of armed conflict on the sovereign's own internal use of force: the Russian Federation has never allowed that the Chechen wars it fought in 1994-1996 and 1999-2009 fell to be regulated under the law of armed conflict. ${ }^{164}$

So, imagine the terrorist attacks of the 1890s and 1900s sourced to a single non-state, well-organized, transnational terrorist group in the 2000 s. It is quite plausible that an armed conflict of a sufficiently sustained and intense nature to meet the criteria of Common Article 3 could be said to exist. 165 Of course, if the level of violence were deemed too sporadic, too low a level of intensity to rise to an armed conflict, only domestic law informed by international human rights law would apply to limit state action under a law enforcement paradigm. It must be emphasized,

163. Some have alleged that the 1999 apartment bombings in Moscow and elsewhere in the Russian Federation, in particular, were covert Russian operations intended to provoke the second Chechen War.

164. Russia is a signatory to the European Convention on Human Rights and free to derogate from certain of its provisions" [i]n time of war or other public emergency threatening the life of the nation . . See European Council, Convention for the Protection of Human Rights and Fundamental Freedoms art. 15, Sept. 4, 1950, E.T.S. No. 5. It has not done so. See Isayeva v. Russia, App. No. 57950/00, 41 Eur. H.R. Rep. 791, 824 \& 836 (2005).

165. Compare Prosecutor v. Haradinaj, Case No. IT-04-84bis-T, Judgment, ๆ1 392-399 (Int'l Crim. Trib. for the Former Yugoslavia Nov. 29, 2012) (finding an armed conflict triggering Common Article 3 through the application of its Tadic factors to circumstances in Kosovo in 1998), with HCJ 769/02 Pub. Comm, against Torture in Israel v. Israel, 2006(2) PD 459, 475-76 [2006] (Isr.) (the Supreme Court of Israel finding "a continuous state of armed conflict" to exist, citing "an unceasing, continuous and murderous barrage of attacks, which are directed against Israelis wherever they are, without any distinction between soldiers and civilians or between men, women and children. Within the framework of the current terror barrage, more than 900 Israelis have been killed from September 2000 until the present, and thousands of other Israelis have been injured. Thousands of Palestinians have also been killed and injured during this period."), and Abella v. Argentina, Case 11.137, InterAm. Comm'n H.R., Report No. 55/97, OEA/Ser.L./V/II.98 doc. 6 rev. 153 (1997) ("The most difficult problem regarding the application of Common Article 3 is not at the upper end of the spectrum of domestic violence, but rather at the lower end. The line separating an especially violent situation of internal disturbances from the "lowest" level Article 3 armed conflict may sometimes be blurred and, thus, not easily determined. When faced with making such a determination, what is required in the final analysis is a good faith and objective analysis of the facts in each particular case."), and id. at 19 154-156 (the Inter-American Commission on Human Rights finding that a 30 hour clash between Argentine armed forces and attackers of La Tablada military base triggered Common Article 3). See also Kenneth Watkin, Use of Force During Occupation: Law Enforcement and Conduct of Hostilities, 94 INT'L REv. RED CROSS 267, 312 n.279 (2012) (noting Algerian insurgent's claim that bombs in crowded markets were elements of his warfare strategy, "I had my bombs planted in the city because I didn't have the aircraft to transport them.'). 
therefore, that although the fact of armed conflict is the trigger for the law of armed conflict, what constitutes armed conflict remains quite controversial and subject to debate. ${ }^{166}$ But let the assumption be that the violence of such attacks would be intense and sustained enough to constitute an armed conflict.

That would imply an armed conflict "not of an international character" (a "NIAC") against a non-state actor. It is also possible that such a nonstate actor could obtain sufficient control over territory to establish the predicates for the application of AP II to the conflict. In such a circumstance, at the very least, customary international humanitarian law, as well as domestic law (which itself must comply with international human rights law) would govern the use of force, targetability, and detention powers employed by the state.

If other states came to the aid of the sovereign afflicted by this nonstate actor's armed attacks, the armed conflict would remain a noninternational armed conflict. No new body of law would be added to the mix. If states came to the aid of the heretofore unprivileged belligerents, the armed conflict may become an international armed conflict under Common Article 2 (an "IAC"). Much of the same customary international law would apply, as would the treaty law governing international armed conflicts, displacing as lex specialis the domestic law and, where applicable, the international human rights law. 167

What has changed? How has the law of armed conflict-a specialized body of public international law-expanded to restrict state action within its own borders, or perhaps outside its borders when it engages in military action against non-state enemies? In the past, a state's absolute sovereignty-recognized as the core and concrete basis of the law of nations-excluded the intrusive power of any other authority save that imposed by overpowering force of arms. But today sovereignty is not nearly as absolute. Consider, for example, the understanding of this relationship expressed by the International and Operational Law Department of the United States Army Judge Advocate General's Legal Center and School, the epicenter of training for America's military lawyers:

Under international law, sovereignty is the ultimate benefit of statehood. Inherent to sovereignty is the notion that a State should be free from outside interference. International law, however, seeks

166. See, e.g., Gloria Gaggioli, RePort of THE EXPERT MEeting OF THE INT'L COMM. OF THE RED CROSS ON THE USE OF FORCE IN ARMED CONFLICTS: INTERPLAY BETWEEN THE CONDUCT OF HOSTILITIES AND LAW ENFORCEMENT PARADIGMS 1 (Nov. 2013).

167. It should be noted that the application of the concept of lex specialis is subject to debate among scholars. For a helpful summary of different positions, see Watkin, supra note 165, at 301-14. 
to regulate State conduct. States "trade" aspects of sovereignty in order to reap the benefits of the international legal system. While this may seem natural in cases of warfare between states (or international armed conflict), it becomes more contentious in cases of internal or non-international armed conflict. ${ }^{168}$

Seem natural? Not to Martens, diplomats, or many international law scholars of his generation! State sovereignty has lost its absolute character. The individual has ascended to a new status in international law. But "more contentious" would hardly capture the view Martens might have held of such a change. The inclusion of the mini-Convention of Common Article 3, let alone AP II, was simply not within his conception of international law.

The dilution of the plenary nature of state sovereignty is related to this emergence of the individual as an international law subject and, in the context of armed hostilities, to the recognition that war need not be interstate to produce massive humanitarian suffering. ${ }^{169}$ The greatest sea change in public international law has been the recognition that individual human beings are not merely objects of international law, but subjects of international law. Absolute sovereignty is incompatible with that notion. Of course, "absolute sovereignty" was redundant to Martens's generation of public international lawyers; it was impossible for sovereignty to be anything else but absolute.

This is also both a cause and an effect of the erosion of the notion that the law of armed conflict displaces all other law. In a world in which humans have rights that are neither granted by states nor removable at their whim, it follows that the law of armed conflict can only be a law that is given priority in case of some conflicts with other laws, but has no more absolute power than the concept of sovereignty could have. Consider, for example, the commentary by Jean Pictet-as noted above, the "main architect" of the Geneva Conventions-concerning the application of the Geneva Convention IV concerning the protection of civilians when the interest of states in doing so is at its lowpoint:

168. LAW OF ARMED CONFLICT DESKBOOK, supra note 101, at 2.

169. Ticehurst, supra note 121 , at 132 ("In contrast to positive law, natural law is universal, binding all people and all States. It is therefore a non-consensual law based upon the notion of the prevalence of right and justice. Natural law was to a great extent displaced by the rise of positivist interpretations of international law. ... However, the judgment of the Nuremberg Tribunal, which to a great extent relied on natural law to determine the culpability of the Nazi high command, confirmed the continuing validity of natural law as a basis for international law in the twentieth century."). 
What would the position be, it may be wondered, if both the Parties to an armed conflict were to deny the existence of a state of war. Even in that event it would not appear that they could, by tacit agreement, prevent the Conventions from applying. It must not be forgotten that the Conventions have been drawn up first and foremost to protect individuals, and not to serve State interests. 170

As with an international armed conflict, so to with a conflict "not of an international character." Pictet's Commentary to Common Article 3 notes the distance traveled from the view of international law as the purview of states alone, a law of self-imposed limitations that only states could make and to which only states could be held accountable. In its explication of the phrase "each Party" with which the article begins its description of obligations, the Commentary notes:

The words "each Party" mark the great progress which the passage of a few years had brought about in international law. Until recently it would have been considered impossible in law for an international Convention to bind a non-signatory Party - a Party, moreover, which was not yet in existence and which need not even represent a legal entity capable of undertaking international obligations. ${ }^{171}$

The Commentary goes on to note that the guarantee of humane treatment that the "mini-Convention" of Article 3 provides is absolute: "No possible loophole is left; there can be no excuse, no attenuating circumstances." 172

This change in international law was slow and recent. ${ }^{173}$ Although the Geneva Conventions were drafted "to safeguard the dignity of the human person, in the profound conviction that imprescriptible and inviolable rights are attached to it even when hostilities are at their height," the

170. Pictet, supra note 30 , at 21 .

171. Id. at 37 .

172. Id. at 38 .

173. RESTATEMENT (THIRD) OF THE FOREIGN RELATIONS LAW OF THE UNITED STATES, $\$ 101$ (1987) ("International law, as used in this Restatement, consists of rulcs and principles of general application dealing with the conduct of states and of international organizations and with their relations inter se, as well as with some of their relations with persons, whether natural or juridical.'). That is a dramatic change from the previous Restatement in 1965. See id. $\$ 101$, reporter's note 1 ("As compared with that [previous] definition, this section indicates that international law has ceased to apply exclusively to state and international organizations and now deals also with their relations with individuals and juridical persons."). See also id. $₫ 906$, cmt. a ("TThe increasing recognition of the rights of private person, whether natural or juridical, under international law, has led to a variety of remedies and arrangements to protect these rights."). 
treaties themselves did not clearly affirm the existence of "rights" per se until 1949.174 As late as 1950, the U.S. Supreme Court noted (in a footnote, since the matter must have seemed so clear) that there was no remedy for individual grievances under the 1929 Geneva Conventions save the intervention of state authorities on behalf of their nationals. 175 This footnote was the basis of the holding of the D.C. Circuit in Hamdan $v$. Rumsfeld, that the Geneva Conventions conferred no rights enforceable in U.S. courts. 176 Whatever other reason the Supreme Court had for overruling this position, ${ }^{177}$ reliance on a judicial opinion that reflects the state of the relationship between sovereignty and human rights in 1950 (interpreting a 1929 treaty) does not correspond with the change that relationship has undergone.

To reflect on this changed relationship is not to overlook tensions that remain between individual rights and sovereignty. ${ }^{178}$ Nor should support for the arrival of individuals as rights-bearing subjects in international law be misconstrued as a claim asserting sovereignty's dwindling importance. Sovereignty remains a cornerstone concept of international law. ${ }^{179}$

Nevertheless, the two concepts are not always in harmony. As the Harvard historian David Armitage noted recently, "how to protect universal human rights in a world of sovereign states, each of which jealously guards itself from interference by outside authorities, remains

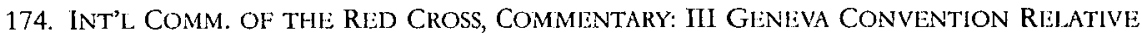
to the TrEatment of Prisoners of War 90-91 (Jean S. Pictet ed., 1960).

175. Johnson v. Eisentrager, 339 U.S. 763, 789 n.14 (1950) ("We are not holding that these prisoners have no right which the military authorities are bound to respect. The United States, by the Geneva Convention of July 27, 1929. 47 Stat. 2021, concluded with forty-six other countries, including the German Reich, an agreement upon the treatment to be accorded captives. These prisoners claim to be and are entitled to its protection. It is, however, the obvious scheme of the Agreement that responsibility for obscrvance and enforcement of these rights is upon political and military authorities. Rights of alien enemies are vindicated under it only through protests and intervention of protecting powers as the rights of our citizens against foreign governments are vindicated only by Presidential intervention.").

176. Hamdan v. Rumsfeld, 415 F.3d 33, 39 (D.C. Cir. 2005).

177. Hamdan, 548 U.S. at 627.

178. Indeed, dissenting from the denial of certiorari in Noricga v. Pastrana, 130 S.Ct. 1002, 1002 (2010), Justice Thomas (joined by Justice Scalia), argued in favor of providing "much-needed guidance" on "whether the Geneva Conventions are self-executing and judicially enforceable." It is interesting to note that the United States District Court that sentenced him to prison for drug-related offenses held that the Third Gencva Convention was self-executing and provided "a right of action in a U.S. court for violation of its provisions," Id. at 1003, n.2, while the United States argued in the court of appeals that "no court of appeals has held that the provisions of the Geneva Conventions are judicially enforceable in any context." Id. at 1004.

179. U.N. Charter art. 2, f甲 1, 4, 7; Corfu Channel Case (U.K. v. Alb.), 1949 I.C.J. 4, 35 (Apr. 9) (U.K. "self-help" violates respect for sovereignty); Military and Paramilitary Activities in and Against Nicaragua (Nicar. v. U.S.), 1986 I.C.J. 14, 111 (June 27). 
one of the most pressing dilemmas of international politics."180 Debates concerning humanitarian intervention in recognition of a "responsibility to protect" (R2P) expose the stress fractures in that foundation that result from the increasing respect for individual rights. ${ }^{181}$ The R2P concept supposes (in varying forms) either the legal obligation or simple permissibility of one state's intrusion into another state's sovereign sphere in order to protect the individual rights of foreign nationals oppressed by that state. (A responsibility to protect a state's own nationals could be restated as the existing right to self-defense.) Its clearest formulation was made by Anthony D'Amato long before the term was coined: "If we take human rights seriously, we cannot insulate a government's actions towatd its own citizens by an artificial sovereign boundary." $182 \mathrm{R} 2 \mathrm{P}$ exposes the tension developed by elevating individuals to the level of rights-bearing subjects of international law: "sovereignty as responsibility" is an inversion of the classical conception of "sovereignty as absolute autonomy." 183

The Bush Administration's "global war on terror" model (described in Part I) asserted LOAC authority to pursue non-state actors wherever they roam. That approach paid minimal regard to state sovereignty, but not necessarily because of increased concern for individual rights. It would seem to be for the state party to the armed conflict with a non-state party to decide for itself that another state is unwilling or unable to pursue its non-state adversaries hiding or harbored there. Similarly, a coalition of states might arrogate to themselves the determination that a third state is unable or unwilling to protect the human rights of that third state's own nationals, in that way accruing responsibility for the coalition to act.

But there the similarities end. A decision by that imagined coalition to intrude on the sovereignty of that state in order to protect the third state's nationals invites a response from the state suffering that incursion on its sovereignty-the decision is an affront to the sovereign's assertion to be the protector of its own people.

Thus, while sovereignty remains a still-essential concept of international law, the erosion of the concept of absolute sovereignty results in a

180. David Armitage, The Declaration of Independence: The Words Heard Around the World, WALL. ST. J, July 5-6, 2014, at C1.

181. Hathaway, supra note 15 , at 499,502 .

182. Anthony D'Amato, Nicaragua and International Law: The "Academic" and the "Real," 79 AM. J. INT'J. L. 657, 659 (1985).

183. Hathaway, supra note 15 , at 538 . Thus, the General Assembly could adopt without vote Resolution 60/1 World Summit Outcome, which affirms support for traditional conceptions of sovereignty in its fifth paragraph while asserting Chapter VII authority to intervene without the consent of states perceived not to be satisfying their responsibilities to protect essential human rights. See G.A. Res. 60/1, q 5 \& 139, U.N. Doc. A/RES/60/1 (Oct. 24, 2005). 
Martens Clause that extends its principles much further than its drafter could have imagined. This is an understanding of its importance that the United States did not display in its aggressive response to the attacks of September 11, 2001. The Bush Administration thought that its military action within a non-consenting state as part of a "global war on terror" rendered the individual rights of so-called unlawful combatants subject neither to the "protection" of a state's law enforcement rights regime (subject to international human rights law) or of the law of armed conflict nor to the "empire" of sovereign protection of those within its borders.

This is a view that the Martens Clause should be read to forbid.

\section{The Martens Clause and Armed Conflict}

Step back now from the minutiae of particular armed conflicts at specific historical moments to reflect on the continuing importance of the Martens Clause. In doing so, a fundamental principle of social organization should be noted. In the absence of war, the default rule in a state of free citizens, self-governed by law, is one that prizes the liberty of the individual: whatever has not been prohibited is permitted. ${ }^{184}$ This way of thinking encourages innovation, creativity, and human ingenuity in society.

This philosophy of default permissiveness extends to interactions in the society of states. Indeed, this principle has been viewed by many to be central to the decision by the Permanent Court of International Justice in the famous case of The Lotus: outside of the prohibitions expressed by international law, states are free to act as they will. ${ }^{185}$

In wartime, however, such liberty is not always desirable, either at the level of individual human fighters or at the level of those states or nonstate organizations that direct the fighting. The Martens Clause reverses this presumption in peacetime civil affairs to reflect the special case of military conduct in wartime. It rejects the view that, because a specific practice or tactic or action is not prohibited, it is therefore permitted. Quite the opposite, it reminds us that an exhaustive accounting of inhumanity is impossible, and therefore a general rule must apply to limit the ingenious human cruelty that occurs in armed conflicts. Even if no specific provision might protect a particular group of belligerents or suspected belligerents or innocent civilians, the Martens Clause reminds all

184. The realization of this principle, for example, was a turning point in the final years of the Soviet Union. ARCHIE Brown, The GORBACHeV FACTOR 146 (1996).

185. Armin von Bogdandy \& Markus Rau, The Lotus, in MAX PI.ANCK ENCYClOPEDIA OF PUBLIC INTERNATIONAL LAW (2006), available at http://opil.ouplaw.com/view/10.1093/law:epil/9780199231690/law-9780199231690-c162. 
that these groups "remain under the protection and empire of the principles of international law..., the laws of humanity and the requirements of the public conscience."

This is the perspective taken in the ICRC Commentaries to the Additional Protocols to the Geneva Conventions. 186 And it appears to have been the view held by Martens himself. Fighting for the inclusion of his clause, Martens rhetorically asked the other delegates to consider the effect of passing in silence over disputed questions: "This uncertainty, is it advantageous to the weak? Does the weak become stronger because the duties of the strong are not determined? Does the strong become stronger because his rights are defined and, therefore, restricted?" 187

The Bush Administration argued that the law of armed conflict sanctioned its military action following the September 11 th attacks but imposed no limits on how to conduct that action, the Geneva Conventions not directly speaking to the "transnational" conflict with "unlawful enemy combatants" fighting for al-Qaeda. As the prosecution of the "war on terror" demonstrated, an entitlement to use military force without corresponding restrictions-a jus ad bellum without jus in bello-invited the very abuses that the law of armed conflict seeks to diminish.

The Bush Administration justified this view in the perceived novelty of the conflict with transnational terrorism. The Obama Administration has also embraced, at the very least, an ambiguity about what aspects of the law of armed conflict apply to its fight with transnational non-state actors and how terms in that law (such as "imminence") might be applied. But such a conflict is not novel. The real change, unacknowledged by both presidential administrations, was what really mattered. That was the change in the relationship between state and individual in international law. That change makes more difficult the assertion that the law of armed conflict authorizes the use of force without imposing duties on the state. And that change makes the Martens Clause more applicable in the twenty-first century than its drafter scarcely could have imagined.

Martens, an eloquent speaker, argued forcefully in the subcommission he chaired that "the supreme object of our common efforts" should be to draft "an act of education which is to enter in future into the program of

186. Zimmermann, supra note 11 , at $\$ 55$ ("There were two reasons why it was considered useful to include this clause yet again in the Protocol. First, despite the considerable increase in the number of subjects covered by the law of armed conflicts, and despite the detail of its codification, it is not possible for any codification to be complete at any given moment; thus the Martens clause prevents the assumption that anything which is not explicitly prohibited by the relevant treaties is therefore permitted. Secondly, it should be seen as a dynamic factor proclaiming the applicability of the principles mentioned regardless of subsequent developments of types of situation or technology.').

187. HULL, supra note 85 , at 217. 
military instruction." 188 By this he meant to educate not only the commanders in the field, and those who staffed military headquarters, but those occupying positions of political leadership:

Our present task is to remind peoples of their duties, not only in time of peace but also in time of war. Our mission has been well defined from the very beginning of our common labors: we wish to elaborate, in a spirit of concord, humanity, and justice, the uniform bases for the instructions which the Governments will pledge themselves to give to their armed land forces .... It is our unanimous desire that the armies of the civilized nations be not simply provided with the most murderous and perfected weapons, but that they shall also be imbued with the notion of right, justice, and humanity, binding even in invaded territory and even in regard to the enemy. 189

And if their work should end in failure? "Under these circumstances it would be impossible to deny to belligerents an unlimited right to interpret the laws of war to suit their fancy and convenience."190

Under the circumstances of the nineteenth and early twentieth centuries, state sovereignty was privileged above all other values as the cornerstone of international law. Today, the evolution of non-international armed conflicts takes place under circumstances in which the value (not to mention the meaning) of state sovereignty is not nearly so absolute. The principles behind the Martens Clause, recognized as customary international law by the International Court of Justice in its advisory opinion on the use of nuclear weapons, apply to regulate all armed conflicts. The Martens Clause prohibits a state that elects to treat a struggle with terrorists as an armed conflict from disavowing the humanitarian protections of the law of armed conflict that must by force of that factual circumstance apply.

\section{CONCLUSION}

One might conclude here by asking what point there is to insisting that states respect the Martens Clause, even this minimalist interpretation. Notwithstanding a provision that makes clear that the application of Common Article 3 "shall not affect the legal status of the Parties to the

188. EYFFINGER, supra note 47, at 298 (quoting speech of Martens, Jun. 6, 1899).

189. Id.

190. Id. 
conflict,"191 states have not been very willing to accept its application. ${ }^{192}$ From the perspective of the non-state actor, is there much reason to believe that a terrorist organization (whether of the classic, small-celled, nineteenth-century revolutionary variety, more modern insurgent groups whose tactics include terrorism, or even organizations such as Hamas or Hezbollah that in some senses govern territory under their control) would likely agree to be bound by international humanitarian law, an invitation to do so in Common Article 3 notwithstanding? ${ }^{193}$ This law expressly prohibits the intentional attack of civilians, often the raison d'etre of the terrorist organization itself. 194 Aside from prohibiting the terrorist's preferred methods of warfare, compliance with the rules for combatant status is a recipe for defeat for non-state actors. As Christopher Greenwood noted with regard to British interpretation of the requirement of a fixed distinctive sign (an element required by Article 4 of Geneva Convention IV to claim prisoner of war status), "[i]t is difficult to imagine any guerrilla movement being able to comply with this requirement and survive." 195 It is even more difficult to believe that a terrorist group would want to comply at all: "[I]t seems impossible to expect that terrorists can be bound by principles of humanity and public conscience. In contrast, their objective is to spread fear by arbitrary attacks. This makes the application of international humanitarian law as a whole--including the Martens Clause-impossible."196

The true value of these obligations, as with any act of self-restraint, is the salutary effect of compliance on the conduct of one's own state. Pictet's commentary, again, says it best:

191. See Common Article 3, supra note 31.

192. William Abresch, $A$ Human Rights Law of Internal Armed Conflict: The European Court of Human Rights in Cbechnya, 16 EUR. J. INT'L L. 741, 756 (2005) ("[S] tates routinely reject the application of the humanitarian law instruments to violence within their borders. In situations that objectively constitute armed conflicts, the application of Common Article 3 is frequently rejected, the application of Protocol II has been accepted by only a handful of states, and the application of Protocol I to a conflict against a national liberation movement has never been acknowledged by the state involved. States refuse to apply humanitarian law to internal armed conflicts for teasons that are more political than legal.").

193. See generally Provost, supra note 25. Common Article 3 concludes with a penultimate statement that "The Parties to the conflict should further endeavor to bring into force, by means of special agreements, all or part of the other provisions of the present Convention."

194. See, e.g., Protocol I, supra note 100, at art. 51 ("The civilian population as such, as well as individual civilians, shall not be the object of attack. Acts or threats of violence the primary purpose of which is to spread terror among the civilian population are prohibited.").

195. Christopher Greenwood, International Humanitarian I au' (laws of War): Revised Report for the Centenial Commemoration of the First Hague Peace Conference 1899, in THE CENTENNIAL OF THE FIRST international. Peace Conferlance: Reports \& Conclusions (Frits Kalshoven, ed., 2000) (describing passage in 1958 British Manual of Military Law unchanged from initial appearance shortly after 1899 Hague Conference).

196. Heintze, supra note 130 , at 433 . 
If an insurgent party applies Article 3, so much the better for the victims of the conflict. No one will complain. If it does not apply it, it will prove that those who regard its actions as mere acts of anarchy or brigandage are right. As for the de jure Government, the effect on it of applying Article 3 cannot be in any way prejudicial; for no Government can possibly claim that it is entitled to make use of torture and other inhuman acts prohibited by the Convention, as a means of combating its enemies. ${ }^{197}$

Pictet noted that Common Article 3 set a "compulsory minimum" for conduct in an armed conflict. "At the same time," he wrote, its words are also "an invitation to exceed that minimum."198 The Martens Clause rests on the same essential idea. The law sets a minimum standard of conduct from which neither states nor non-state actors may lawfully depart. At the same time, it is an invitation to do better.

197. Pictet, supra note 30 , at 37 .

198. Id. 


\section{APPENDIX}

Terrorist Attacks in Moscow, January 1, 1998 to January 24, 2011

Date Location Casualties

Jan. 1, $1998 \quad$ Subway bombing 3 injured

Apr. 26, 1999 Intourist Hotel bombing Approx. 11 injured

Aug. 31, $1999 \quad$ Manezh Shopping Center. 1 killed; 40 injured bombing

Sept. 9, $1999 \quad$ Apartment building bombing 94 killed; 249 injured

Sept. 13,1999 Apartment building bombing 119 killed; 200 injured

Aug. $8,2000 \quad$ Subway bombing 13 killed, 90 injured

Feb. 5, $2001 \quad$ Subway bombing 20 injured

Oct. 23-26, 2002 Dubrovka Theater attack 129 of 850 hostages killed

July 5, $2003 \quad$ Music Festival bombing 16 killed, 60 injured

Dec. 9, $2003 \quad$ National Hotel bombing 6 killed, 13 injured.

Feb. 6, $2004 \quad$ Subway bombing 41 killed, 134 injured.

Aug. 24, 20042 planes from Domodedovo 90 killed Airport

Aug. 31, $2004 \quad$ Subway bombing 10 killed, 50 injured

Aug. 13, $2007 \quad$ Moscow-Petersburg train 60 injured

Nov. 27, $2009 \quad$ Moscow-Petersburg train 26 killed, 100 injured

Mar. 29, $2010 \quad$ Subway bombing 40 killed, approx. $100+$ injured

Jan. 24, 2011 Domodedovo Airport bombing 36 killed, approx. 180 injured

Source: CBC-Radio Canada News, Attacks in Moscow: 1996-2011 (Jan. 24, 2011), http://www.cbc.ca/news/world/attacks-in-moscow-1996-2011-1.1008425. 
